\title{
On the Seedling Structure of Gymnosperms. II.
}

\author{
BY \\ T. G. HILL, A.R.C.S., F.L.S., \\ University of London; University and Goldsmiths' Colleges;
}

AND

E. DE FRAINE, B.SC., F.L.S.,

University of London; Goldsmiths' College.

With Plate XV and eleven Figures in the Text.

ABIETINEAE (continued).

\ANY investigators have recorded various observations on the seedlings of this group of the Gymnosperms. Lestiboudois ${ }^{1}$ drew attention to the fact that the number of cotyledons is often double the number of the bundles of the root, e.g. Pinus Pinea, \&c.; further, he pointed out that this is not at all constant even in the same species; for, while some of the vascular strands of the root may give rise only to one cotyledonary trace, others may give rise to more than one.

Duchartre $^{2}$ described the occurrence of polycotyledony in the Abietineae and certain Cupressineae, and remarked upon the rarity of the phenomenon in Funiperus, Thuja, and Cupressus. He also observed the inconstancy of the number of seed-leaves in these polycotyledonous plants, and the lack of a direct relation between the number of bundles coming in from the cotyledons.

Van Tieghem ${ }^{3}$ and Strasburger ${ }^{4}$ cite examples of species of Pinus and other Gymnosperms which show this same variation both as regards the number of seed-leaves and the relations of their bundles to the primary rootstructure.

De Bary ${ }^{5}$ gave a brief general description of the bundle system of the seedlings, with a few details of the transition phenomena. Dangeard ${ }^{6}$

${ }^{1}$ Lestiboudois : Phyllotaxis anatomique (Ann. Sci. Nat., Bot., sér. 3, t. x, 1848).

${ }^{2}$ Duchartre : Mémoire sur les embryons qui ont été décrits comme polycotylés, Id. 1848 .

${ }^{3}$ Van Tieghem: Sur la symétrie de structure des plantes vasculaires (Ann. Sci. Nat., Bot., sér. 3 , t. xiii, I $870-I$ ).

${ }^{4}$ Strasburger: Die Coniferen und die Gnetaceen (Jena, I872).

5 De Bary: Comparative Anatomy of the Phanerogams and Ferns (Oxford, I884).

${ }^{6}$ Dangeard: La mode d'union de la tige et de la racine chez les Gymnospermes. Compt. Rend, Feb. 1890.

[Annals of Botany, Vol. XXIII. No. XC. April, I909.] 
states that if there are two cotyledons, the root is diarch; if three seedleaves are present, a triarch root-structure results; but, if the number of cotyledons be more numerous, agreement between their number and the number of poles in the root no longer obtains.

Dangeard was the first to work out in any detail the relationships between the cotyledonary strands and the root-structure; his results are best expressed by the following quotation: 'Chaque faisceau de la racine, soit libérien, soit ligneux, s'insère sur deux traces cotylédonaires, ce qui peut être indiqué par le rapport $\frac{2 n}{n}$ ' He then mentions some exceptions :-

' $\mathrm{I}$. A ce que l'une des traces cotylédonaires se divise en deux pour donner insertion à un faisceau de la racine, les autres traces cotylédonaires conservent la disposition ordinaire : ce fait correspond aux rapports $\frac{5}{3}, \frac{7}{4}, \frac{9}{5}$, $\frac{11}{6}, \frac{13}{7}$.

2. A ce que l'une des traces cotylédonaires se réunit à une autre sans servir à l'insertion: ce cas correspond aux rapports $\frac{7}{3}, \frac{9}{4}, \frac{11}{5}, \frac{13}{6}, \frac{15}{7}$ '.

It may here be remarked that these relations, according to our experience, do not occur so regularly as the above indicates. Further, that on our hypothesis Dangeard's first case $\left(\frac{2 n}{n}\right)$ corresponds to all the seed-leaves being half-cotyledons; his second case corresponds to one seed-leaf being a whole cotyledon, and the rest half-cotyledons; while his third case corresponds to one seed-leaf being a subsidiary cotyledon and the rest half-cotyledons.

In a later paper Dangeard ${ }^{1}$ describes many histological features in the seedlings of some Gymnosperms, and also transition-phenomena which will be referred to when necessary. ${ }^{2}$

Masters ${ }^{3}$ described the morphology of the seedlings of many species, and showed how variable is the number of seed-leaves in one and the same genus.

\section{TSUGA.}

Tsuga canadensis, Carr. The normal number of cotyledons is apparently three, Masters ${ }^{4}$ gives $3-5$ as the range in number, and Dangeard ${ }^{5}$

1 Dangeard: Recherches sur les plantules des Conifères (Le Botaniste, sér. 3, I892).

${ }^{2}$ We did not discover the existence of this paper until after this present communication had been written, and it is for this reason that mention was not made of Dangeard's work in our Part I (Annals, 1908). He briefly describes and illustrates the transition-phenomena in Cupressus funebris Endl., C. Corneyana Hort., C. Lindleyi Klotsch, Actinostrobus pyramidalis Miq., Thuja orientalis L., and Taxus baccata, Tourn. We are in agreement with him in essentials; but as regards details we have not found the bifurcation of the cotyledonary strand and rotation of the protoxylem quite so strongly marked in Thuia orientalis and Taxus baccata as he indicates.

${ }^{3}$ Masters : Comparative Morphology, Anatomy and Life-history of the Coniferae (Journ. Linn. Soc., Lond., Bot., xxvii, I 89I ). Notes on the Genera of Taxaceae and Coniferae. Id. xxx, I895.

4 Masters : 1895, loc. cit.

${ }^{5}$ Dangeard : Le Botaniste, iii, I892. 
states that three are generally present. Their structure resembles many of the Cupressineae; the amount of transfusion tissue is very small, and there may be made out, towards the bases of the seed-leaves, a few xylem elements situated in a centripetal position. Resin ducts are absent.

The seed-leaves form a short but fairly well-marked cotyledonary tube, and in this region the bundle of each becomes somewhat tangentially elongated, an arrangement which is retained during the inward passage. After the central region of the hypocotyl has been reached, each trace splits into two halves, the bifurcation generally appearing first in the phloem. Each half-bundle then rotates around the protoxylem which acts, as it were, as the pivot. The wood is thus exposed, and the protoxylem takes up its exarch position, in some instances very gradually. The opposing groups of phloem elements effect a junction so that a triarch root-structure obtains. These changes agree with the brief description given by Dangeard ${ }^{1}$.

Tsuga diversifolia, Mast., as far as can be ascertained from seedlings having much secondary thickening, does not differ in any essential feature from $T$. canadensis.

\section{ABIES.}

The structure of the cotyledons calls for but little comment; mention need only be made of three features. In Abies sibirica, $A$. Veitchii, $A$. balsamea, $A$. amabilis, and $A$. magnifica var. Shastensis, each seed-leaf has two resin ducts situated in each corner towards the dorsal surface; transfusion tracheides also are present in varying amounts; and, finally, a cap of broad, elongated, thin-walled elements abuts directly on to the dorsal surface of the phloem.

Abies pectinata appears to be somewhat abnormal, for the seed-leaves have no resin ducts, and transfusion tissue has not been observed.

In all the species examined each cotyledon had a single bundle which retained its endarch character until the central region of the hypocotyl had been reached.

Abies sibirica has three or four cotyledons. The examination of a specimen with the former number showed the transition to be identical with what obtains in Tsuga canadensis, and resulted in the formation of a triarch root-structure. A seedling (Series B) which had four cotyledons behaved somewhat differently, and requires some description. All the seed-leaves were quite free for the greater part of their length, but towards the basal region two of them were fused together, so that a transverse section at this level had the appearance illustrated in the first figure of Diagram I. The four bundles of the seed-leaves retained their identity within the hypocotyledonary axis for some time, and were surrounded by a practically closed ring formed by the fusion of the fibrous elements of the four phloem masses.

${ }^{1}$ Dangeard, loc. cit. 
The bundles $a, b$, and $c$ underwent bifurcation of their vascular elements, and rotation of the protoxylems as described for Tsuga canadensis and illustrated in Diagram I. The strand $d$, however, performed differently. In the upper part of the hypocotyl, $d$ converged towards $a$ (Diagram I, Fig. 2), and at the same time a rearrangement of the xylem elements began which ultimately resulted in the protoxylem occupying an exarch position: the phloem of $d$ showed no signs of bifurcation but fused with the adjoining portion of the bast of $a$ (Diagram I, Figs. 3 and 4). At lower levels of the hypocotyl the protoxylem of $d$ gradually made its way through the inter-
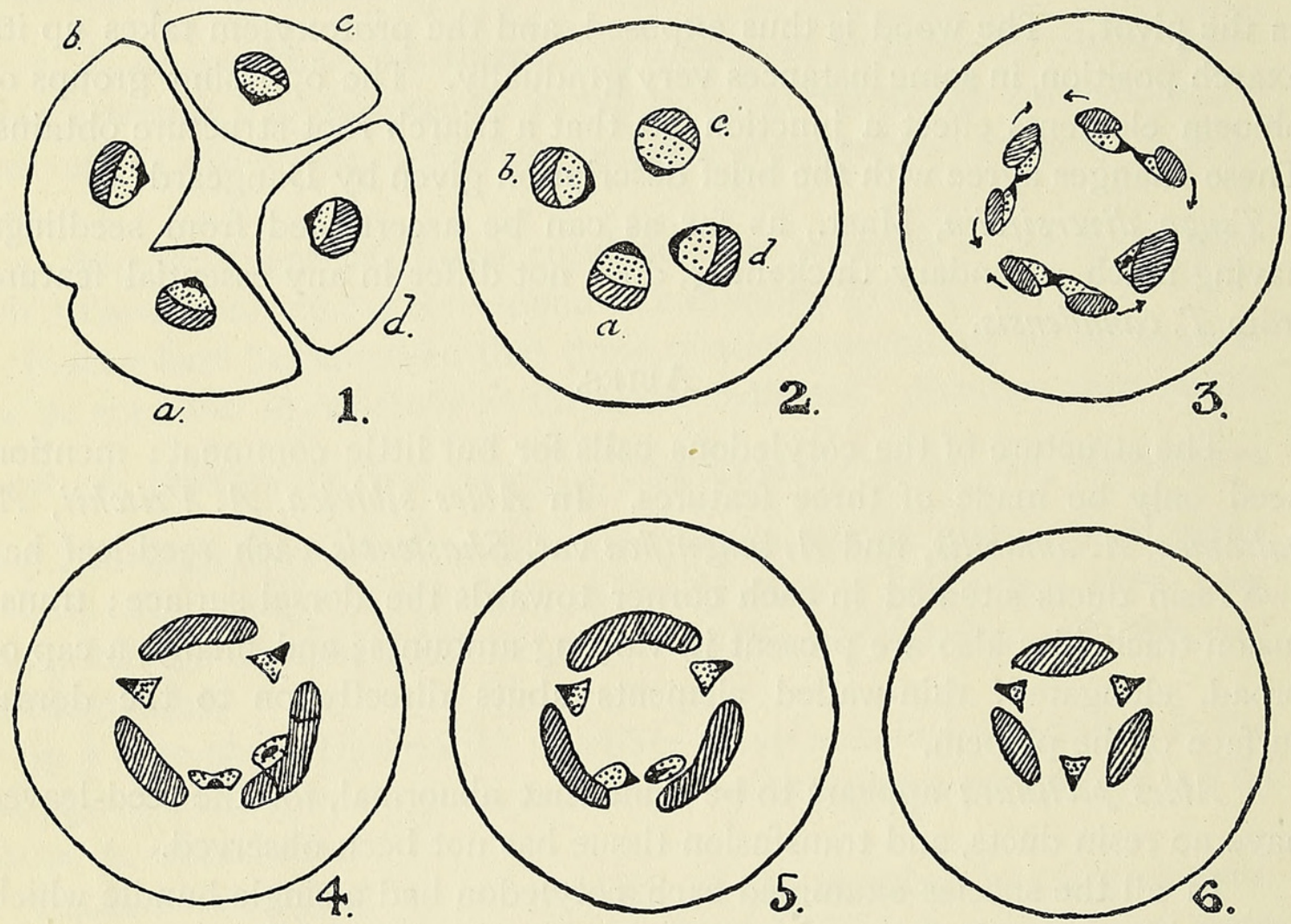

Diagram I. Abies sibirica. In this, and in all the following text-figures, the protoxylem is indicated by black areas, the metaxylem by dots, and the phloem by shading.

vening metaxylem elements, and effected a junction with the same tissue of $a$ (Diagram I, Figs. 4-6). A triarch root-structure was thus attained.

Different views may be held regarding the features described for this particular individual : the seedling may represent a late stage in the splitting of one seed-leaf to form two cotyledons, but a comparison with what obtains in Cupressus torulosa ${ }^{1}$ shows important and obvious features of difference. The bundles $a$ and $d$ of Abies sibirica do not converge, and by a comparatively simple sequence of events give rise to one pole of the root as in the case of Cupressus torulosa ; in the seedling of Abies sibirica, the phloem of $a$ bifurcates and one portion accompanies the bast of $d$ to effect a junction

\footnotetext{
${ }^{1}$ Part I, Annals of Botany, 1908, p. 700, Diagram 4.
} 
with half the phloem of $c$; again the protoxylems of $a$ and $d$ retain their identity longer than would be expected if these two strands represented the bundles of half-cotyledons ; further, from what obtains in the similar seedling of Cupressus torulosa, and in other plants to be described hereafter, the bundles $a$ and $b$ would be expected to form one pole of the root, since these are the traces of the two cotyledons which fuse together ; finally, the protoxylem of $d$ becomes exarch, and, at a lower level, makes its way through the metaxylem to join with the protoxylem of $a$. These characteristics are not those associated with the strands of either half-cotyledons or subsidiary cotyledons; for these reasons this particular seedling may be looked upon as an example showing a tetrarch root-structure becoming triarch in a very short space. The fusion of the seed-leaves $a$ and $b$ is the beginning of the formation of a cotyledonary tube which is not at all uncommon in these polycotyledonous forms.

Abies Veitchii. Of this species, only one seedling, having three cotyledons, was available. The transition-phenomena leading to the formation of the root-structure, although similar to what occurs in A. sibirica (Series A), is not nearly so well marked as in the last-named plant. The redistribution of the xylem elements in order to bring the protoxylem into the exarch position is of a very indefinite nature, there being in two bundles no separation of the xylem masses into two halves followed by a rotation (cf. Funiperus ${ }^{1}$ ); the xylem of one bundle did, however, partly split in the manner described for Actinostrobus, ${ }^{2}$ but the $\mathrm{V}$ very soon closed up again.

Abies balsamea, Mill. All the plants of this species had four cotyledons, each with one vascular bundle.

The transition resembles $A$. sibirica in all essentials, but the rotation of the protoxylem is not so well marked in all cases, a character which recalls that obtaining in Callitris rhomboidea. ${ }^{3}$

Series $A$. Two of the cotyledonary bundles underwent bifurcation and rotation to form two poles of the triarch root; the two remaining seedleaf-traces together formed the third pole.

Series $B$. All the four vascular bundles derived from the seed-leaves showed bifurcation and rotation of their vascular elements, a tetrarch rootstructure resulting. The exarch position of the protoxylem, however, was brought about partly by the rotatory movement and partly by an indefinite rearrangement of the xylem-elements.

Series $C$ proved more interesting. Of the four cotyledonary bundles, three exhibited bifurcation and rotation of the xylem as in the other plants of this species; in a very short space, however, half the xylem of one of these strands, which, for convenience may be termed $c$, fused with the xylem of the adjoining fourth seed-leaf-trace $(d)$, and the combination of the two gave rise to one pole of the triarch root-structure. The fourth bundle was

\footnotetext{
${ }^{1}$ Part I, Annals, 1908, p. 696.

${ }^{2}$ Part I, Id. p. 703.

Part I, Id. p. 706.
} 
clearly that of a half-cotyledon, and the bundle $c$, although it first behaved as the strand of a whole cotyledon, finally performed as that of a halfcotyledon.

Abies firma, Sieb. and Zucc. One seedling only was available for study. It had four cotyledons, and the transition-phenomena closely resembled those described for $A$. balsamea. The rotation of the xylem was more strongly marked in $A$. firma than in $A$. balsamea.

Abies sachaliensis, as far as our inadequate material indicates, is essentially similar to $A$. firma.

Abies pectinata, DC. The usual number of cotyledons is eight, which
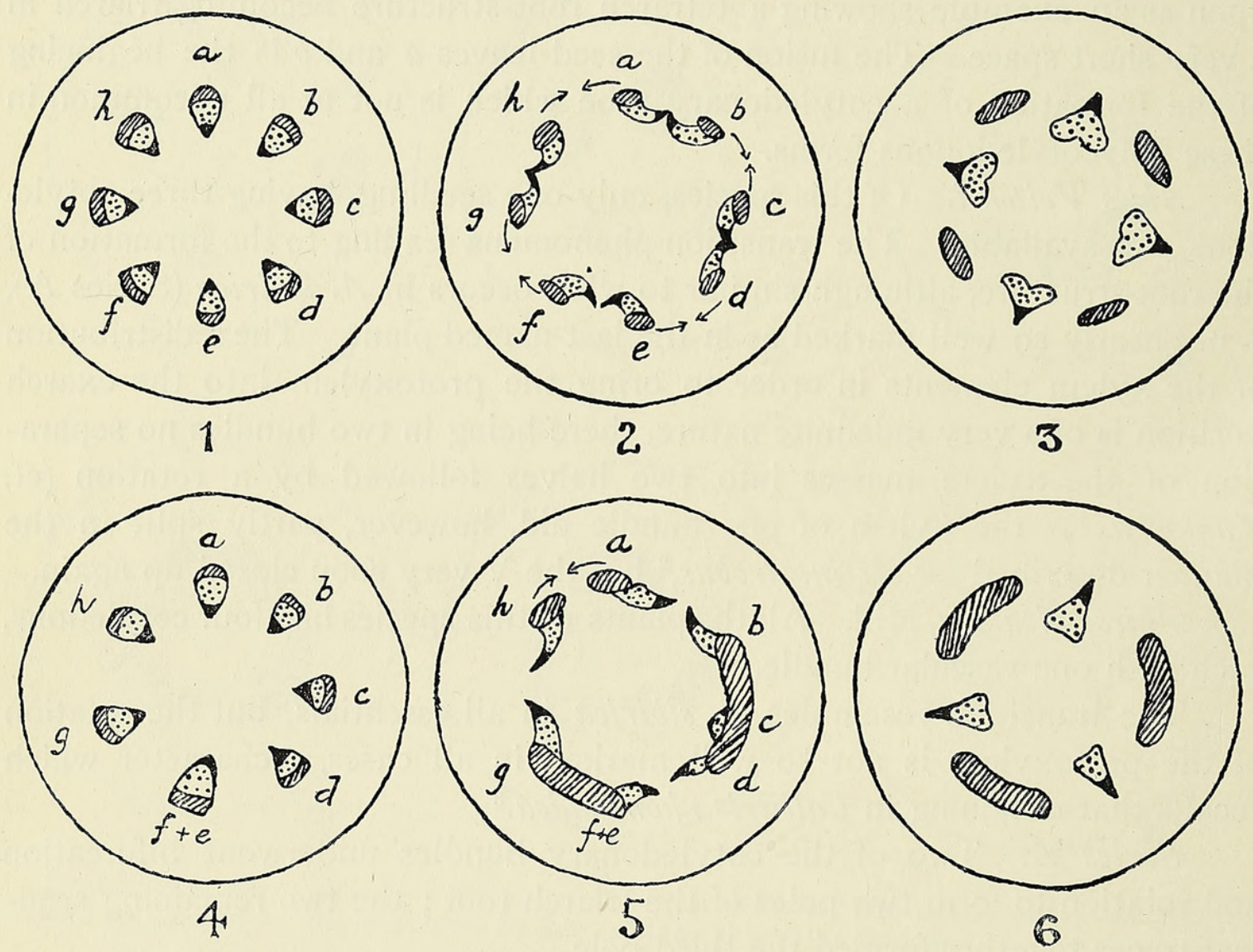

Diagram 2. Abies pectinata.

in some cases form a short tube. The root is triarch in structure, which arrangement is arrived at in two different ways.

In the first case, the eight seed-leaf-traces form a well-marked zone in the upper part of the hypocotyl ; rotation then takes place, the protoxylems of two adjacent bundles are thus brought into contact and gradually assume the exarch position, concurrently the eight phloem masses fuse in pairs. The inward rotation of the metaxylem still continues until the fusion of each pair is completed, and hence a tetrarch root-structure results. At a lower level a triarch arrangement supervenes by the obliteration of one xylem group and the fusion of the two lateral phloem masses (Diagram 2, Figs. I, 2 and 3 ). 
In other instances, a different course is pursued. In the upper part of the axis two of the cotyledonary traces fuse together, and, at a slightly lower level, two others effect a junction, so that six bundles result which by rotation of the xylem and fusion of the phloem, as in the case first described, form a triarch root. (Diagram 2, Figs. I, 4, 5 and 6.)

The first seedling of the plant under consideration clearly represents an instance of four cotyledons having split to form eight; while in the second case, six of the seed-leaves represent half-cotyledons, and the two which play no prominent part in the transition are to be considered subsidiary seed-leaves.

Abies amabilis, Forb. The one available seedling of this plant had eight seed-leaves which fused to form a short cotyledonary tube.

The transition-phenomena took place in a similar manner to those in A. sibirica; the bundle of one cotyledon played no part in the process, and thus is to be placed in the category of subsidiary cotyledons. Of the remaining bundles, each formed a pole of the root, which organ was 7 -arch in the higher region, but was reduced to 6-arch, and finally 5-arch.

Abies magnifica var. Shastensis. Here, again, only one seed germinated, giving rise to a seedling with nine cotyledons. The transition resembled both $A$. sibirica and $A$. pectinata. The bundles of six of the seed-leaves underwent bifurcation of the phloem and rearrangement of the xylem to form six poles of the 7 -arch root, two of the cotyledons behaved as in $A$. pectinata, and together formed the remaining pole of the root, the remaining cotyledon merely fused with its immediate neighbour and played no further part. Thus of the nine seed-leaves, six represent wholecotyledons, two are half-cotyledons, and one is subsidiary.

The 7 -arch root was reduced to a 6 -arch structure by the gradual disappearance of one phloem mass, and the fusion of the two protoxylems originally separated by the obliterated bast.

\section{PICEA.}

The cotyledons do not call for much comment. In transverse section they are triangular in shape; the mesophyll is very loose with a few secretory cells; the transfusion tracheides are not very numerous, and are more abundant in $P$. ajanensis and $P$. morinda than in $P$. mgra; resin ducts are absent; and fibrous elements occur on the dorsal side of the phloem, they are not, however, so numerous as in Abies. Each seed-leaf has one endarch vascular strand which shows no vascular rearrangement until entry into the hypocotyl has been gained. The cotyledons, at their basal regions, may fuse together laterally to form a more or less well-defined cotyledonary tube ; $P$. ajanensis has the tube fairly well defined, $P$. morinda less so, and in P. nigra there is no lateral union of the seed-leaves. 
Picea ajanensis. The seed-leaves vary in number from six to nine, for the genus Masters ${ }^{1}$ states that the number of cotyledons is five to fifteen.

Series $A$. Six cotyledons. The endarch collateral bundles move towards the centre of the axis, and are arranged in three pairs (Diagram 3, Fig. I, $a . b ., c . d$., and $e . f$.), alternating with the three plumular traces derived from the foliage leaves from the first whorl $(p . \mathrm{I}, p .2, p .3)$. The centripetal displacement continues so that the individuals of each pair of cotyledonary strands become contiguous; finally a complete vascular ring is formed. At a lower level the protoxylems of each pair of bundles rotate towards each other, the metaxylem, in two cases out of three, still being in continuity, and the phloem still forming a practically uninterrupted ring (Diagram 3, Fig. 2). This rotation of the xylem before the phloem and metaxylem has split is somewhat unusual, although it does sometimes occur in Tsuga canadensis. Then the original pairs of seed-leaf-traces separate so as to leave the protoxylem exposed and, at the same time, the fusion
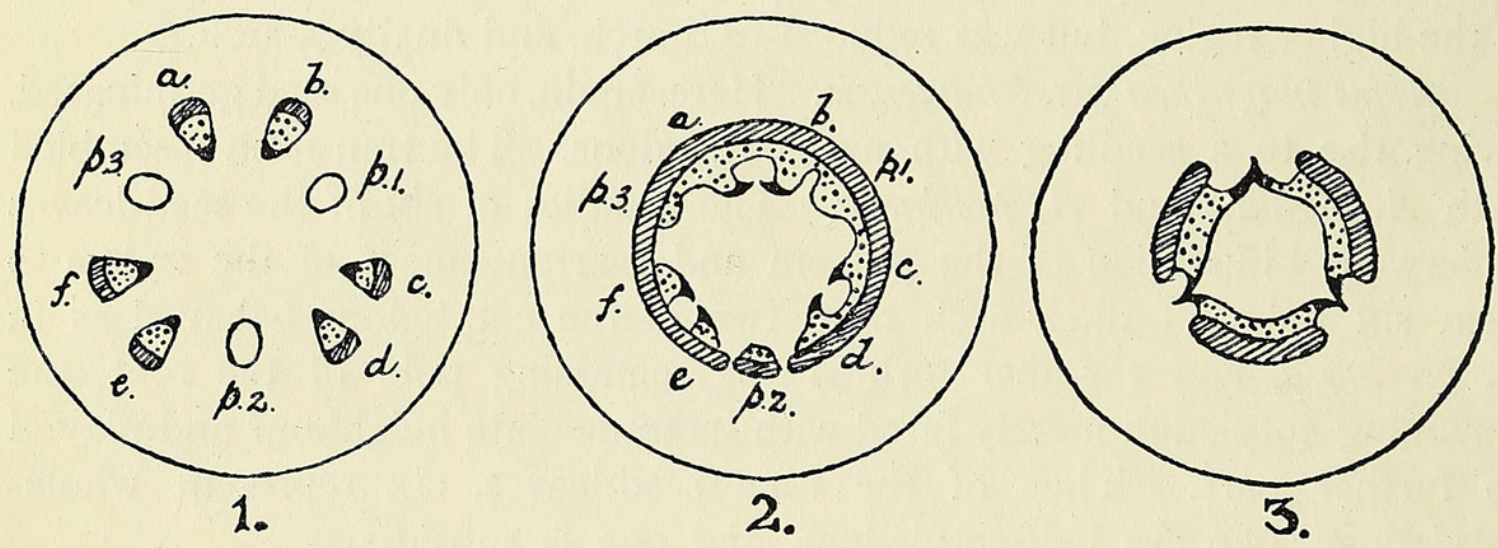

Diagram 3. Picea ajanensis.

of the plumular bundles with the strands of the seed-leaves becomes so intimate that it is no longer possible to delimit their boundaries. There thus results three phloem masses with much metaxylem on their inner sides alternating with three groups of protoxylem elements (Diagram 3, Fig. 3). The completion of the rearrangement results in a triarch rootstructure. From these facts it is clear that each seed-leaf represents a half-cotyledon.

Series $B$. Seven cotyledons. The transition was effected as in Series A, but instead of there being three pairs of cotyledon-traces, there were two pairs and a group of three. The root as before was triarch. The behaviour of the seed-leaf-strands showed that one cotyledon was subsidiary and the rest were half-cotyledons.

Series $C$. This seedling was very much younger than the rest and had eight seed-leaves, of which two were subsidiary and six were half-cotyledons. A triarch root was formed. 
Series $D$. Nine cotyledons. The changes resulting in root-structure were the same as described for the previous individual, the vascular ring was, however, so close as to render the absolute identification of the separate bundles almost impossible. A triarch root resulted; and of the cotyledons, three may be considered subsidiary and the rest, half-cotyledons. The transition took place in a manner identical to that followed by Abies pectinata (see Diagram 2, Figs. I, 4, 5, and 6).

Picea nigra, Link. The number of seed-leaves is six or seven, and the rearrangement of their vascular tissues takes place as in $P$. ajanensis and requires no further detailed description. Attention, however, may be drawn to one seedling (Series C). It has been seen that one seedling of Abies sibirica provided an example of a tetrarch root-structure becoming triarch in a very short space; this particular seedling of $P$. nigra illustrates the same change in a more marked degree. The plant had seven seed-leaves, the bundles of which behaved in a normal fashion; two gave rise to one pole of the root, and two, together with a subsidiary strand, gave rise to another, the remaining two commenced to rotate so that it was naturally expected that a triarch root would result. This, however, did not occur; the last pair of bundles mentioned, which commenced redistribution of their vascular elements, stopped the rearrangement so that a diarch root resulted. These changes recall the similar ones which occur in some species of Mirabilis.

Picea morinda, Link. The seed-leaves vary from eight to ten, and the transition-phenomena are the same as in $P$. ajanensis, a triarch root being formed.

Picea alba, Ait, is described by Dangeard ${ }^{1}$. The number of seedleaves varies from five to seven, the mesophyll is homogeneous and resin ducts are absent. In the case of a seedling with six cotyledons, the transition resembles in all essentials that described above for $P$. ajanensis.

\section{CEDRUS.}

The cotyledons are numerous, varying in number from nine to eleven, which is in agreement with the number found by Masters ${ }^{2}$. Their structure calls for but little comment; each has a single vascular bundle which is endarch throughout the whole length of the member. Transfusion tracheides in our material were absent; older cotyledons might exhibit them, for a certain number of immature elements occurred in places where they might be supposed to be formed. Fibrous elements occur on the dorsal side of the soft bast, and secretory cells also are abundant. Resin ducts are present in the seed-leaves of $C$. Deodara ; but are absent in the cotyledons of $C$. atlantica. When present, there are two resin-canals in each leaf, one being situated in each of the dorsal corners.

1 Dangeard: Le Botaniste, iii. 1892.

2 loc. cit. 
Towards their bases the seed-leaves fuse together to form a particularly well-marked tube, on the inner side of which foliage leaves are inserted, which indicates that, in the seedling, the apex of the stem is depressed.

\section{Cedrus atlantica.}

Series $A$. The seed-leaf-traces enter the hypocotyl and gradually converge towards the centre, forming a closed ring of vascular tissue with the protoxylem groups in an endarch position. The transition in this species, and also in C. Deodara, is, in essentials, similar to that in Abies pectinata and species of Picea. It is, however, slower than in many of the preceding and foregoing plants. Eight of the bundles form four pairs, and the protoxylems of the vascular strands of each pair rotate towards one another and outwards, so that ultimately a tetrarch root-structure results, the phloem being interrupted opposite the exarch protoxylem masses.

The ninth bundle was much slower in its movements than the rest; ultimately it converged towards, and fused with one of the strands lateral to it, and its protoxylem also showed indications of an outward rotation. The fate of these particular elements was extremely hard to trace, for the adjoining bundles had already formed a pole of the root and their metaxylems were very compact. However, the appearances warrant the assumption that the protoxylem of this ninth bundle fused with the same tissue of the lateral strand mentioned above, thus this particular strand played the part of the bundle of a subsidiary cotyledon; but, at the same time it showed characters usually associated with the trace of a half-cotyledon.

Series $B$. This seedling had ten cotyledons, the bundles of which behaved in the same manner as the majority in Series A; six bundles paired to form the poles of the triarch root, and the remaining four played no important part in the transition, and are therefore to be classed as subsidiary.

One other individual (Series C) was also examined, but the vascular ring formed by the eleven cotyledonary bundles and the intervening plumular traces was so compact as to make it impossible to follow the changes with any degree of satisfaction. It is probable that of the eleven cotyledons, eight were half-cotyledons and three subsidiary; the resulting root-structure was tetrarch.

Cedrus Deodara. The number of seed-leaves is eleven, and the transition follows seemingly precisely that obtaining in $C$. atlantica. We add the slight qualification because the cotyledonary bundles are so numerous, and, in the hypocotyl, are situated so closely together that it is impossible to identify them with absolute certainty.

In the seedlings examined, the resulting root-structure was pentarch, which in one case became reduced to tetrarch. 
Attention also may be drawn to another feature. In Series A there were eleven seed-leaves and the same number of leaves in the first foliage whorl of the plumule. Of these foliage leaves one was much larger than the rest, with a more massive vascular bundle which showed a greater vascular differentiation. Further, it fused on to the cotyledonary tube before any of its fellows, and its bundle took up a position slightly more external than the other strands; it also retained its vascular differentiation for a longer period than the other bundles of the first foliage whorl. The probable significance of this will be dealt with below (see Pimus Pinea, Series C).

\section{PinUs.}

The cotyledons vary in number from three to about twelve, and their structure does not differ, excepting in a few features, in certain species, from the foregoing plants. Resin ducts are generally present, the only two species in which they have not been observed being $P$. halepensis and $P$. Coulteri. In $P$. Pinea, $P$. Gerardiana, and $P$. canariensis each cotyledon has two resin ducts situated in the dorsal corners of the leaf; in $P$.australis, $P$. insignis, $P$. contorta, $P$. contorta var. Murrayana, $P$. montana var. gallica, and $P$. sylvestris each seed-leaf has one resin duct situated immediately on the dorsal side of the vascular bundle or else in between the two halves of the divided trace (see Diagram 4, Fig. I). The general rule is for each cotyledon to have a single vascular strand ; there are, however, exceptions, thus in P. montana var. galica and P. contorta var. Murrayana, some of the seed-leaves have two separate vascular strands.

The cotyledonary bundles may show no rearrangement at all in the seed-leaf, as in $P$. Pinea, $P$. Thunbergii, $P$. Gerardiana, and $P$. halepensis; or they may undergo bifurcation of the phloem and rotation of the xylem before entry into the hypocotyledonary axis, as in $P$. Coulteri, $P$. canariensis, $P$. australis, $P$. insignis, $P$. contorta, $P$. contorta var. Murrayana, $P$. montana var. gallica, and $P$. sylvestris.

The bundles of $P$. Pinea and $P$. Gerardiana, very occasionally show one or two metaxylem elements on the ventral side of the protoxylem, the strands thus being very slightly mesarch. Fibrous elements on the dorsal side of the soft bast are generally present ; and, finally, the majority of the species examined exhibit in varying degrees a lateral fusion of the cotyledons towards their bases; the best cotyledonary tubes were seen in $P$. Pinea and $P$.canariensis, in the other species the tube was either very short or incomplete.

Pinus Pinea. Excellent figures representing different stages in the germination of this plant are given in Sachs's Text-book. ${ }^{1}$

1 Sachs: Text-book, Oxford, I882, p. 508. 
Series $A$ and $B$. Eleven cotyledons were present each with one massive endarch collateral bundle, which became tangentially elongated as the cotyledonary node was approached.

The transition took place in the manner described for Cedrus atlantica and other plants; the seed-leaf bundles rotated in pairs giving rise to a pentarch root-structure, the remaining cotyledonary bundle took no part in the vascular rearrangement, and the seed-leaf to which it belonged thus is to be classed as a subsidiary member, while the rest are half-cotyledons. This agrees with the outline given by Strasburger ${ }^{1}$, who mentions that the cotyledons vary from II-4, and also with more extensive description by Dangeard ${ }^{2}$ who gives many figures to illustrate the course of the bundles, and enters fully into histological details.

Series $C$. The number of seed-leaves was nine, eight of which formed a well-marked cotyledonary tube. The ninth also fitted into the tube, but was clearly out of place. In the hypocotyl the vascular strand derived from this ninth seed-leaf was situated within the zone formed by the other cotyledonary bundles, and was orientated obliquely. Gradually, it passed outwards, rotating on its own axis through an angle of about $90^{\circ}$, and fused with the nearest cotyledonary trace. From its behaviour and position we conclude that this ninth seed-leaf is in reality not a cotyledon at all, but a foliage leaf out of place.

This point, taken in conjunction with the peculiarity described in Cedrus Deodara (Series A), is of some interest as it shows a second way in which the number of cotyledons may have been increased.

We look upon the case of Cedrus Deodara as an earlier stage in the formation of a seed-leaf from a foliage member of the first plumular whorl. It may also be remarked that Tansley and Thomas, in the discussion on seedlings at the British Association Meeting at York, expressed their opinion that in some cases the number of cotyledons may be increased by the displacement of leaves of the first foliage whorl.

Pinus Thunbergii, Parl., closely resembles $P$. Pinea.

Pinus Gerardiana, Wall. The only seedling available had ten seedleaves ${ }^{3}$, the majority of the vascular strands of which behaved like those of $P$. Pinea. Some description, however, is necessary on account of the part played by one of the cotyledonary bundles. All the bundles entered the axis as collateral structures and formed, with the traces derived from the plumule, a close vascular cylinder. One seed-leaf-strand then bifurcated and rotated to bring its protoxylem into the exarch position. A resin duct very soon was formed opposite this protoxylem. The rest of the cotyledonary traces behaved as in $P$. Pinea, one being subsidiary and the rest

\footnotetext{
1 Strasburger, loc. cit.

${ }^{2}$ Dangeard, loc. cit.

${ }^{3}$ Masters (loc. cit.) gives $3^{-8 .}$
} 
rotated in pairs so that a pentarch root resulted. During these changes resin canals developed opposite the four remaining protoxylem groups in exactly the same way as in $P$. Pinea.

Pinus halepensis, Mill., closely resembles $P$. Gerardiana; there are, however, more whole-cotyledons in $P$. halepensis, and, further, the bifurcation and rotation of the bundles of these whole-cotyledons may take place at a higher level.

\section{Pinus Coulteri, D. Don.}

Series A. A well-marked tube was formed by the thirteen cotyledons ${ }^{1}$, the bundles of eleven of which were endarch and collateral throughout; the remaining two showed bifurcation of the phloem and rotation of the xylem in different degrees, before an entry into the axis had been made, a feature not observed in any of the foregoing plants. Within the hypocotyl the phloem of another bundle quickly divided and, at the same time, the protoxylem commenced to take up its exarch position. Thus, there were three bundles which underwent bifurcation of the phloem, and a certain amount of rotation of the xylem : generally, these three bundles would form three poles of the root; but, in this particular case, two only of these particular strands behaved as would have been expected, the third, in the transition region, behaved as a half-cotyledon and with an adjoining bundle formed one pole of the root. The other strands acted as the bundles of either half- or subsidiary-cotyledons.

Series $B$. A similar phenomenon occurred in this seedling. There were eleven cotyledons forming a tube as before; and the bundle of one seed-leaf showed rotation of the xylem and bifurcation of the phloem while still contained within the cotyledon. Within the hypocotyl four other strands showed a similar rearrangement; of these one exhibited the redistribution of vascular elements very fully, but the change came to nothing, the bundle being doomed to play the insignificant rôle of a subsidiary cotyledon.

The theoretical importance of these facts will be dealt with, when like occurrences have been described in other plants.

Pinus canariensis, C. Sm. One plant only was available for examination, which differed in no important feature from $P$. Coulteri. One bundle only showed signs of the rearrangement of the vascular elements while the strand was still contained within the seed-leaf, and no trace showed the curious change especially mentioned as occurring in $P$. Coulteri. There were nine seed-leaves ${ }^{2}$, of which two were whole-cotyledons, three were subsidiary-, and four were half-cotyledons. The root was tetrarch.

\footnotetext{
1 According to Masters (loc. cit.), IO-I 4 cotyledons occur.
}

2 According to Masters (loc. cit.), 6-8 cotyledons. 


\section{Pinus australis.}

Series $A$. Nine cotyledons were present, ${ }^{1}$ the bundles of all of which showed division of the bast and rotation of the xylem for the greater part of their length. Thus, at about the level of the cotyledonary node, there was in each seed-leaf a resin duct occupying a central position towards the upper surface; immediately ventral to this canal the protoxylem was situated, while on each side of the resin tube were the two groups of phloem bounded by metaxylem (Diagram 4, Fig. I). The appearance of these strands within the axis would warrant the assumption that a 9-arch root would result, for the contiguous half-bundles have only to fuse to bring about the typical root-structure. But on tracing the bundles downwards,
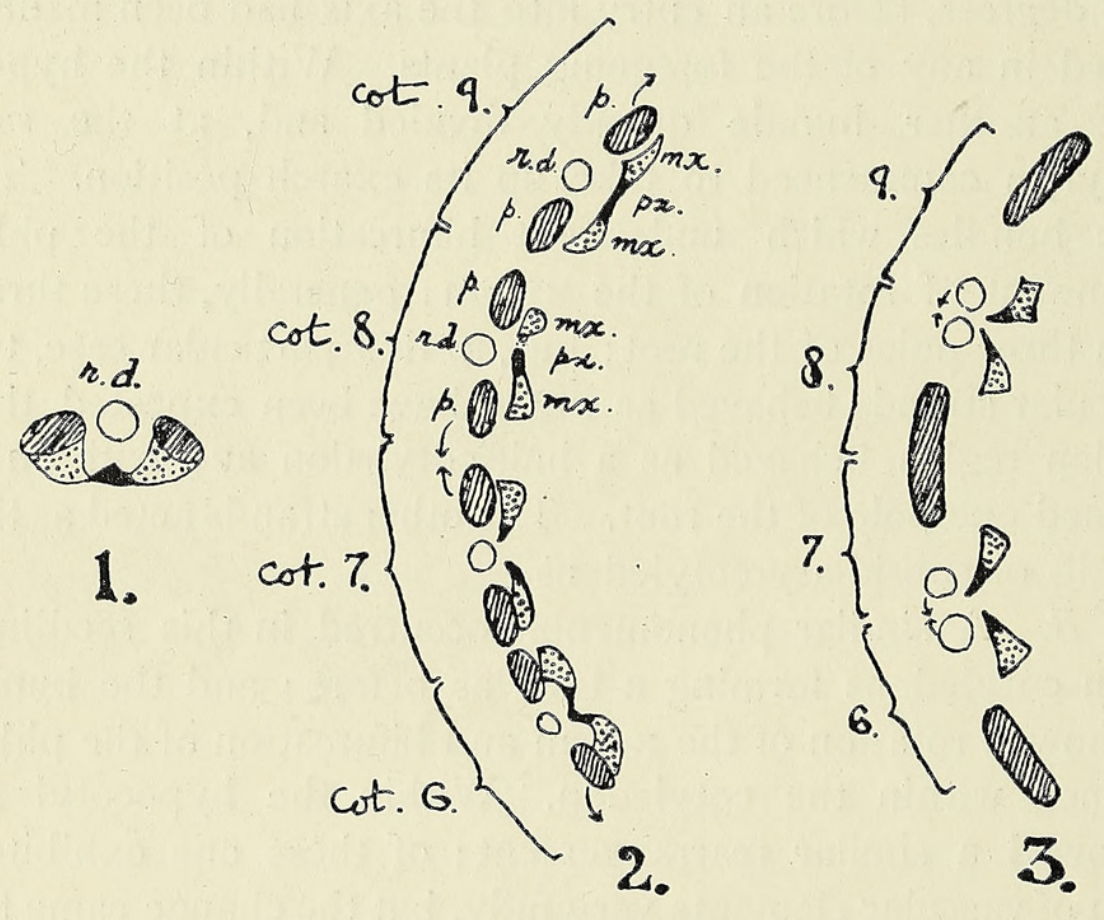

Diagram 4. Pinus australis.

it was found that a 7 -arch root obtained, a result brought about by the obliteration of the half-portions of four bundles, and the fusion of the neighbouring protoxylems. This is illustrated in the accompanying Diagram 4 , Figs. 2 and 3 , where $p$. indicates the phloem; $m x$. represents the metaxylem, and $p x$. stands for the protoxylem of the bundles of the eighth or ninth cotyledon. It will be seen that the vascular tissue of cotyledon 8 has two groups of phloem, two masses of metaxylem, and one collection of protoxylem elements situated on the inner side of a resin duct (r.d.). The same applies to seed-leaf 9. On tracing these structures downwards, the metaxylems pass more towards the centre of the axis, leaving the protoxylems fully exposed, any small amount of metaxylem, which would other-

1 According to Masters (loc. cit.), 7-1o cotyledons. 
wise he in the way, dies out. The neighbouring phloem masses $(p .8$ and $p .9)$ become obliterated, the protoxylems of 8 and 9 approach, ultimately fuse, and, finally, the two resin ducts also effect a junction. The same series of changes takes place between the bundles of the sixth and seventh cotyledons. The rest of the strands behave normally; their protoxylems attain the exarch position before their entry into the axis, and it only remains for the contiguous masses of phloem to fuse in pairs; thus, there is formed a 7 -arch root.

Series $B$. This seedling behaved in an exactly similar manner as regards the details of the transition, excepting for the fact that only two cotyledon-traces fused to form one pole of the root. The number of seedleaves was nine and the root 8 -arch.

Pinus insignis, Dougl.

Series $A$. The five cotyledons ${ }^{1}$ each had the bifurcated bundle as described for $P$. australis; the top of the hypocotyl was thus occupied by ten groups of phloem elements bounded internally by metaxylem. Between each pair of bast bundles a resin duct was situated, on the inner side of which the protoxylem occurred. As the centripetal displacement of these strands took place, the metaxylem rotated further inwards, and the phloem masses fused in pairs, so that a pentarch root-structure quickly obtained.

Series $B$. Of the eight seed-leaves, all exhibited the divided bundle with the exception of one, the strand of which retained its undivided nature throughout its whole course. Within the axis, the same phenomena occurred as have been described for $P$. australis. Thus terming the cotyledonary traces $a, b, c \ldots h ; a$ played a subsidiary part in the formation of the root-structure ; $b$ formed one pole of the root ; $c$ and $d$ together formed one pole in the same manner as the bundles 6 and 7 , and 8 and 9 of $P$. australis (Diagram 4 ); $e$, although its protoxylem contributed to form one xylem ray of the root, must be considered subsidiary ; $f$ formed one pole ; and, finally, $g$ and $h$ showed an unequal bifurcation of the vascular elements, and behaved in an exactly similar manner to $c$ and $d$.

Pinus contorta, Dougl., resembles $P$. insignis pretty closely, although the number of cotyledons is fewer. One plant (Series C) exhibited a very unequal bifurcation of one of the seed-leaf bundles; the smaller portion eventually died out, and the remaining part, together with the adjoining non-bifurcated strand, formed one pole of the root.

\section{Pinus contorta, var. Murrayana.}

The number of cotyledons varies from three to five. Of 25 seedlings examined 2 had three cotyledons ( 8 per cent.), I 8 had four $(72$ per cent.), and 5 had five seed-leaves (20 per cent.). The transition in many 
(Series A-F) took place in exactly the same way as in Series A of P.insignis, although the bifurcation of the phloem and rotation of the xylem occurred generally at a lower level in the cotyledons. The other seedlings showed certain variations which may be briefly alluded to.

Series $G$. Of the four seed-leaves, three behaved in the same manner as in the preceding individuals (Series A-F); but the fourth seed-leaf showed no rearrangement of the vascular elements until entry into the hypocotyl had been made: then, the phloem divided into two portions which passed one on each side away from the xylem, and ultimately fused with the adjoining phloem masses derived from the other strands. The metaxylem similarly divided and moved to each side, leaving the protoxylem exposed; there was no definite rotation of the protoxylem, the bundle followed in the fashion usually associated with Funiperus.

Series $H$. Here also, there were four seed-leaves, the bundles of three of which underwent the redistribution of the vascular tissues while still contained within the cotyledon. The strand of the fourth seed-leaf showed no such rearrangement to begin with, but at a slightly lower level signs of rotation of the xylem were seen, the movement, however, came to nothing, and the bundle finally behaved as a subsidiary structure.

Series $I$. This seedling, in its essential features, recalled the changes described above for $P$. australis and $P$. insignis (Series $\mathrm{B}$ ). The bundles of two of the cotyledons showed the divided phloem and exarch position of the protoxylem before the cotyledonary node was reached; the vascular strands of the remaining two seed-leaves exhibited a similar rearrangement at a lower level within the hypocotyledonary axis. But the division of these two bundles was very unequal ; the two smaller neighbouring portions practically died out, and the two remaining parts together formed one pole of the triarch root (Figs. I and 2, Pl. XV). The two seed-leaves from which these bundles were derived are thus to be looked upon as halfcotyledons.

Series $\mathcal{F}$. The four seed-leaves of this seedling were of unequal size, one (Diagram 5, Fig. I $a$ ) was larger than the rest, $b$ was slightly smaller than $a$ but larger than $c$ and $d$, which were equal in size. The distal region of $a$ showed two small bundles, the phloem masses of which fused at a lower level and, later, the xylem elements of each became joined by the formation of new metaxylem in the intervening space (Diagram 5, Fig. 2). At a much lower level this bundle underwent the usual bifurcation, and so also did the strand of the neighbouring seed-leaf $b$. In each case a resin duct occurred between the two separated portions of the bast. The traces of $c$ and $d$ showed no such division; but, just above the cotyledonary node, they rotated slightly in such a manner that their protoxylems pointed towards one another. Further, $c$ had no resin duct, this structure was, however, present in $d$ and occurred on that side of the bundle towards $e$ 
(Diagram 5, Fig. 3). These two bundles, within the hypocotyl, quickly approached one another, and, as they did so, the rotation became more and more marked; finally they together formed one pole of the triarch root, the other two being produced by the bundles of $a$ and $b$ (Diagram 5, Figs. 4 and 5). From this it is clear that this particular seedling is of some interest;
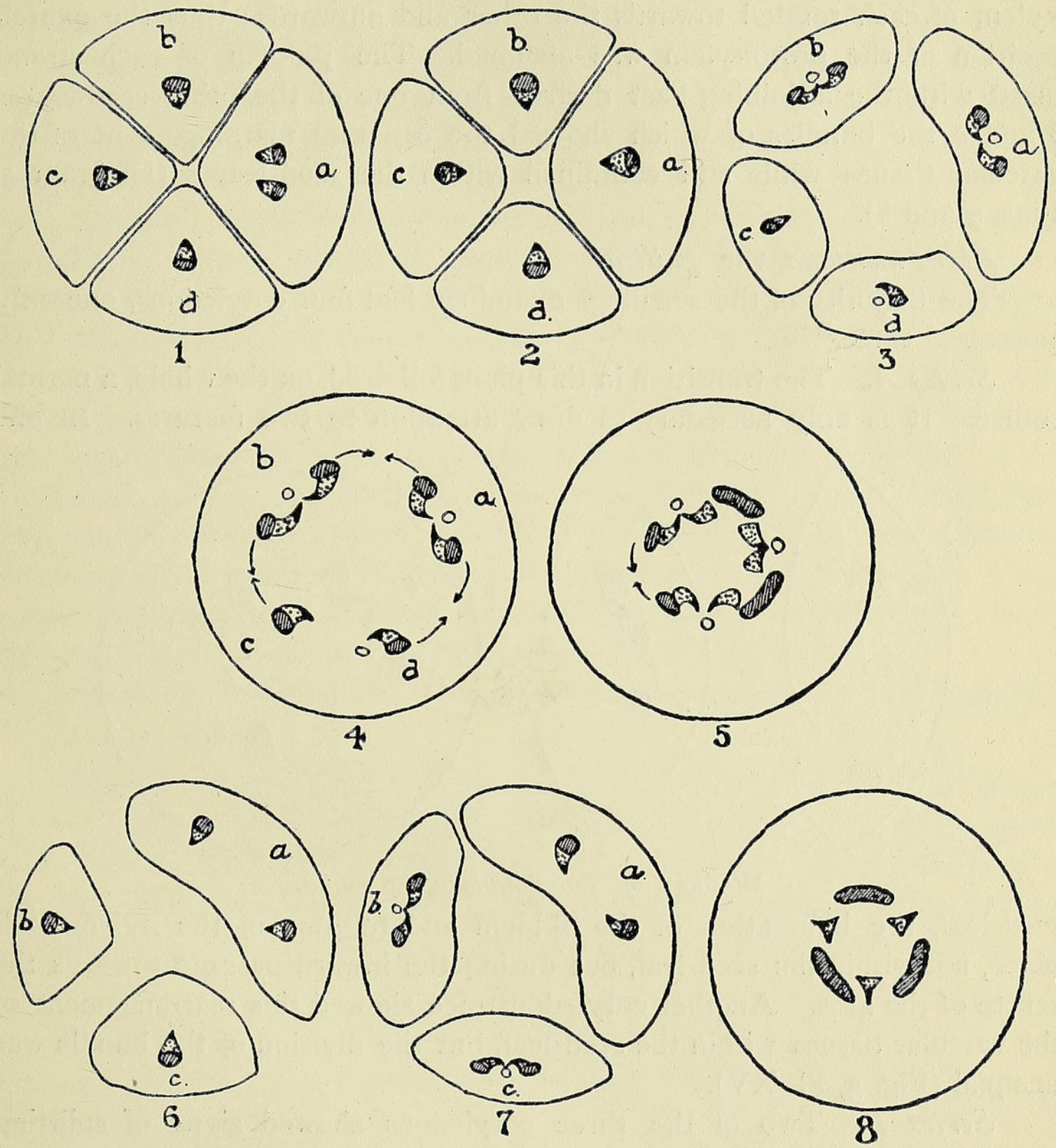

Diagram 5. Pinus contorta, var. Murrayana.

the division of the bundle of $a$, in its apical region, may be looked upon as the initial step towards the splitting of this cotyledon to form two seedleaves; the consummation of which is clearly indicated in the cotyledons $c$ and $d$.

Series $K$ showed an advance upon the last seedling. There were three seed-leaves, one of which was about twice as large as the others. 
This cotyledon showed no external signs of a division, but the examination of the sections showed that there were, throughout its whole length, two distinct bundles, well separated one from the other, the structure strongly recalling the condition which obtains in Ephedra (Diagram 5, Fig. 6, a). The two strands gradually approached one another and entered the axis as entirely distinct endarch structures: no bifurcation took place, but the xylem of each rotated towards the other and outwards; thus the exarch position of the protoxylem was assumed. The phloem of each strand fused with the adjoining bast derived from one of the other seed-leaves $b$ and $c$, the bundles of which showed the essential rearrangement of the vascular tissues while still contained within the seed-leaves (Diagram 5, Figs. 7 and 8 ).

Pinus montana, var. gallica.

The majority of the seedlings examined had four cotyledons, one only possessed three. ${ }^{1}$

Series $A$. The transition in this plant followed, on the whole, a normal course. It is only necessary to draw attention to two features. In one
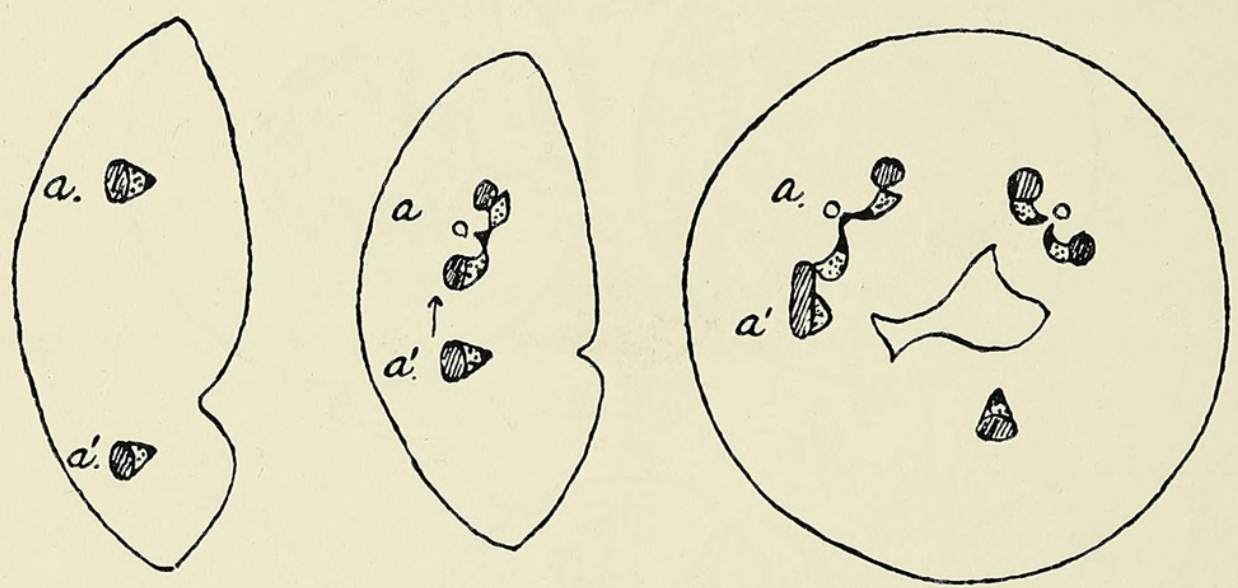

Diagram 6. Pinus montana, var. gallica.

seed-leaf, the bifurcation of the phloem and rotation of the xylem took place, not within the seed-leaf, but during the inward passage towards the centre of the axis. Another cotyledon-trace showed this rearrangement of the vascular tissues within the seed-leaf, but the division of the bundle was unequal (Fig. 3, Pl. XV).

Series $B$. Two of the three cotyledons showed signs of splitting at their apices. Each of these seed-leaves had two vascular strands well separated one from the other. The behaviour of the bundles of one of these cotyledons was exactly the same as those of the seed-leaf $a$ of Pinus contorta, var. Murrayana, Series K (Diagram 5, Figs. 6-8). The changes exhibited by the pair of bundles of the other cotyledon are illustrated in Diagram 6, from which it will be seen that the two strands ( $a$ and $a^{\prime}$ ) approach one another and, at the same time, $a$ undergoes bifurcation of the

1 Masters (loc. cit.), stated that the species has five cotyledons. 
phloem and rotation of the xylem, a rearrangement of tissues which was not shown by $a^{\prime}$. Very quickly a junction between the phloem of $a^{\prime}$ and half the bast of $a$ was effected, and in this condition the vascular strands entered the axis. A pole of the root-structure was entirely formed by the elements derived from the strand $a$, the other bundle $a$ played no part. This means that one bundle $(a)$ is the equivalent of the trace of a whole cotyledon, while the other $\left(a^{\prime}\right)$ represents the bundle of a subsidiary seed-leaf.

It only remains to be remarked, that the bundle of the third cotyledon first showed the characteristic redistribution of the vascular tissues within the hypocotyl, not in the cotyledon. This seedling thus shows three cotyledons on the way to become five.

Series $C$. This seedling, in many respects, resembled the foregoing individual. There were four seed-leaves, the bundles of two of which behaved normally; one as that of a whole-cotyledon, and the other as that of a subsidiary seed-leaf, although the xylem of this last strand retained an abnormal and isolated position beside one of the poles of the diarch root. The two remaining cotyledons fused together at some little distance above the cotyledonary node; so that in transverse section the appearance of this single structure resembled the seed-leaf illustrated in Diagram 6. Of these two strands one bifurcated very unequally; that part of the bundle situated nearest the other strand being very small (see Fig. 3, Pl. XV). The subsequent events resembled those described for Series B sufficiently closely to render any further description unnecessary.

Series $D$ showed similar phenomena, as regards the essential features.

Pinus sylvestris, $\mathrm{L}$.

The following table shows the variation in the number of the cotyledons; it will be observed that the number varies from 3 to 8 , which agrees with the observations of Masters ${ }^{1}$; and that seedlings with six seed-leaves are the commonest. Dangeard ${ }^{2}$ gives $6-9$ as the range in the number of the cotyledons, and enters somewhat fully into the structural details.

\begin{tabular}{|c|c|c|}
\hline $\begin{array}{c}\text { No. of } \\
\text { cotyledons. }\end{array}$ & $\begin{array}{l}\text { No. of } \\
\text { seedlings }\end{array}$ & $\%$ \\
\hline 3 & 2 & $0.2 \mathrm{I}$ \\
\hline 4 & 28 & $2 \cdot 97$ \\
\hline 5 & I I I & I 8. I I \\
\hline 6 & 500 & $5^{2 \cdot 97}$ \\
\hline \multirow{3}{*}{$\begin{array}{l}7 \\
8\end{array}$} & 209 & $22 \cdot 14$ \\
\hline & 34 & $3 \cdot 00$ \\
\hline & Total 944 & \\
\hline
\end{tabular}

The majority of the seedlings examined showed transition-phenomena of exactly the same nature as in many of the foregoing plants, especially 
Pimus contorta var. Murrayana and $P$. montana var. gallica, and agrees with the short description given by Gerard, ${ }^{1}$ so that the table at the end of this paper, showing the relationships between the cotyledons and the rootstructure, will indicate sufficiently well the vascular rearrangements observed. The following three seedlings require a more detailed description.

Series $G$. Six seed-leaves were present, of which two were subsidiary, two showed the bifurcation and rotation of the bundle very clearly and one underwent a similar but very unequal division. The smaller portion of this unequally bifurcated bundle died out, and the remaining part eventually

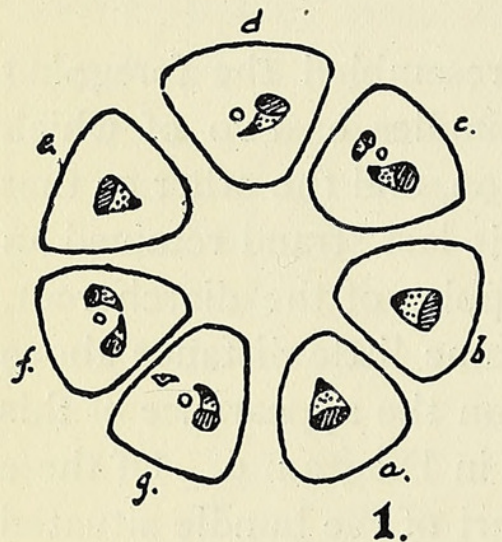

1.

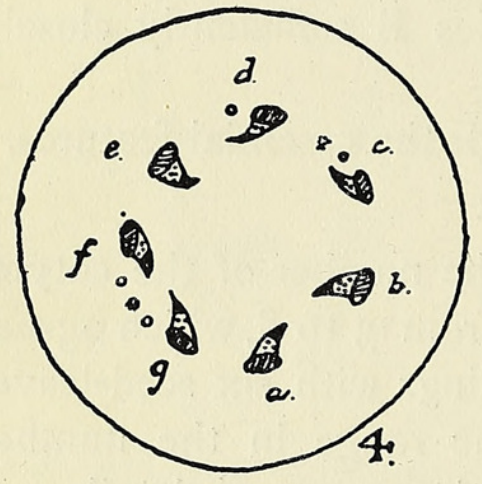

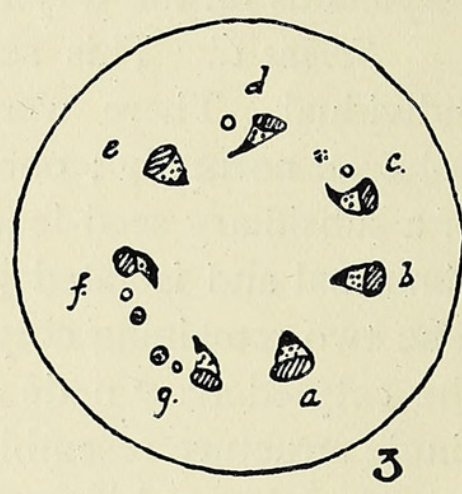

2.

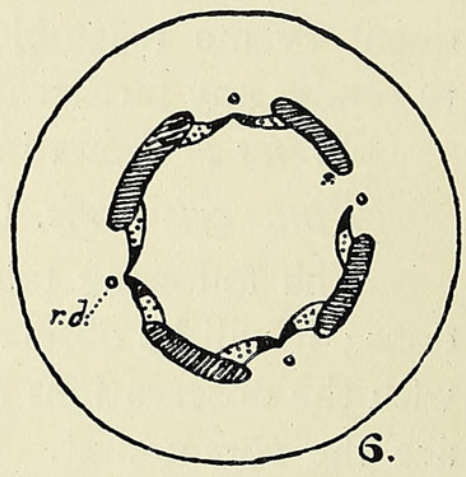

Diagram 7. Pinus sylvestris.

combined with the strand of the adjoining half-cotyledon and formed one pole of the root. This is similar to what occurs in some seedlings of $P$. contorta and $P$. insignis.

Series $H$. The behaviour of the seed-leaf-traces of this seedling was of a complex character, and is illustrated in the accompanying Diagram 7 .

The bundles of the seed-leaves showed various vascular rearrangements; it will be observed (Diagram 7, Fig. I) that the bundles $a, b$, and $e$ are endarch; $d$ has its protoxylem turned towards $e$, and there is a resin duct immediately lateral to it ; $c, f$, and $g$ show the bundles to be bifurcated, but very unequally, and, in the case of $g$, the bifurcation only affects the xylem.

1 Gerard: Recherches sur le passage de la racine à la tige (Ann. Sci. Nat., Bot., xi, I88I). 
Tracing these strands downwards $a, b, d$, and $e$ act as the bundles of halfcotyledons. The trace $d$ may be placed on a plane slightly higher than $a$, $b$, and $e$, since it possesses the dignity of a resin duct. As regards the other bundles, $g$ soon loses its smaller group of xylem elements and combines with $f$ to form a pole of the root, the intervening half-bundle of $f$ having died out (Diagram 7, Figs. 2-5). The two seed-leaves to which they belong are therefore half-cotyledons. The bundle $c$ was of a somewhat undecided character, the phloem of the smaller portion of the bifurcated bundle speedily disappeared (Diagram 7, Fig. 2), and, at a lower level, the corresponding xylem-mass followed suit (Diagram 7, Fig. 4). From this it would be supposed that it would ultimately act as the strand of a halfcotyledon, but at a still lower level (Diagram 7, Fig. 5) the missing xylem reappears and the whole bundle forms one pole of the tetrarch root.

Series $M$ had seven cotyledons, but it is only necessary to draw attention to the bundle of one of them. This strand showed the bifurcation, but the half-bundle of one side soon disappeared; it would therefore be imagined that its performance would be that of the trace of a half-cotyledon, but this was not the case. The whole of the remaining phloem passed over and fused with the similar tissue of the adjoining bundle, and a rearrangement of the xylem took place so that the protoxylem became exarch in position. This is something like what obtained in bundle $c$ of series $\mathrm{H}$ of this same plant.

Pinus maritima. The structure of the seedling of this plant has been worked out by Chauveaud, ${ }^{1}$ whose account shows that this species resembles $P$. sylvestris, $P$. contorta, var. Murrayana, \&c., very closely as regards the features under consideration.

He points out that there is no constant relation between the number of cotyledons and the root-structure; for instance, a plant with five seedleaves may have a pentarch root, while a seedling with seven cotyledons may have a tetrarch root-structure; generally, the seed-leaves are more numerous than the bundles of the root. Further, he recognizes different kinds of cotyledons ; the primitive ones (corresponding to our wholecotyledons), the bundles of which show a vascular rearrangement, viz. the bifurcation of the vascular tissue and the assumption of the exarch position by the protoxylem, as they are traced from the apex downwards; and the non-primitive seed-leaves (corresponding to our subsidiary-cotyledons), in the bundles of which no such rearrangement obtains, they being collateral throughout. They are further characterized by the absence of a resin canal.

Dangeard ${ }^{2}$ also briefly alludes to this species, and gives figures of the seedlings and the course of the bundles.

1 Chauveaud : Passage de la disposition primitive à la disposition secondaire dans les cotylédons du Pin maritime. (Extr. Bull. Mus. Hist. Nat., Paris, I902.)

${ }^{2}$ Dangeard: Le Botaniste, iii, 1892. 
Pinus laricio, Poir, is also described by Dangeard. ${ }^{1}$ The cotyledons vary from eight to ten, and the vascular rearrangements show the same variations as we have found in other species of the genus.

\section{LARIX.}

The structure of the seed-leaves requires but a short description. Resin ducts have not been observed in L. occidentalis; they are present in $L$. leptolepis and L.europaea, in which plants each cotyledon has two canals, situated one in each dorsal corner of the leaf. Each seed-leaf has a single vascular strand ; there may be a little variation in this respect, for one plant showed two separate bundles in one cotyledon similar to what has been described above for Pinus montana, var. gallica and $P$. contorta, var. Murrayana. The vascular bundle is endarch and collateral throughout the whole length of the member, and transfusion tracheides have not been observed. Finally, the cotyledons tend to fuse laterally at their bases to form more or less complete tubes.

Larix occidentalis, Nutt. The only seedling available had six cotyledons, each of which had a single endarch collateral bundle. The vascular rearrangements all took place in the hypocotyledonary axis and resembled those described for Pimus Gerardiana and P. halepensis very closely. Thus of the six seed-leaves, the behaviour of the bundles showed one to be a whole-cotyledon, four to be half-cotyledons, and the remaining one subsidiary.

Larix leptolepis does not differ in any essential feature from L. occidentalis.

\section{Larix europaea, DC.}

Series $A$ and $B$. Six seed-leaves were present, the bundles of which showed the same rearrangements as have been described for Abies pectinata and other plants ; in brief, two pairs of bundles rotated so as to form the two poles of the diarch root, and the remaining bundles merely fused on to the others, taking no part in the transition. Dangeard ${ }^{2}$ states that the transition resembles Picea alba.

Series $C$. In this seedling there were seven cotyledons, the bundles of which behaved somewhat differently from any of the foregoing plants. The first figure of Diagram 8 shows the seed-leaf-traces $a, b \ldots g$ arranged in a zone in the upper part of the hypocotyl. On tracing the strands downwards, $b$ and $c$ approach one another and each fuses with the vascular tissue on either side, their protoxylems rotate towards each other and outwards and form a pole of the triarch root, the strand $b$ contributes most of the protoxylem. These strands are therefore derived from half-cotyledons. The bundle $a$ very soon bifurcates, one half passing over and fusing 
with $g$ and the other portion joining with a small plumular trace $(p l . t)$. The two compound bundles thus formed (Diagram 8, Fig. $3, g+\frac{1}{2} a$, and pl. $t+\frac{1}{2} a$ ) behave as half-cotyledons and form one pole of the root. The fusion between the half portion of $\alpha$ and $g$ is very intimate, which makes the allocation of values rather difficult. It is simpler to consider $\alpha$ as the strand of a whole-cotyledon, and $g$ as that of a subsidiary seed-leaf. The bundles $d, e$, and $f$ all converge; $e$ then bifurcates, one-half joining up with $d$ and the other part fusing with $f$ (Diagram 8, Fig. 2). The protoxylem of $e$ is left in situ (Diagram 8, Fig. 3) for a time, but at a lower level it
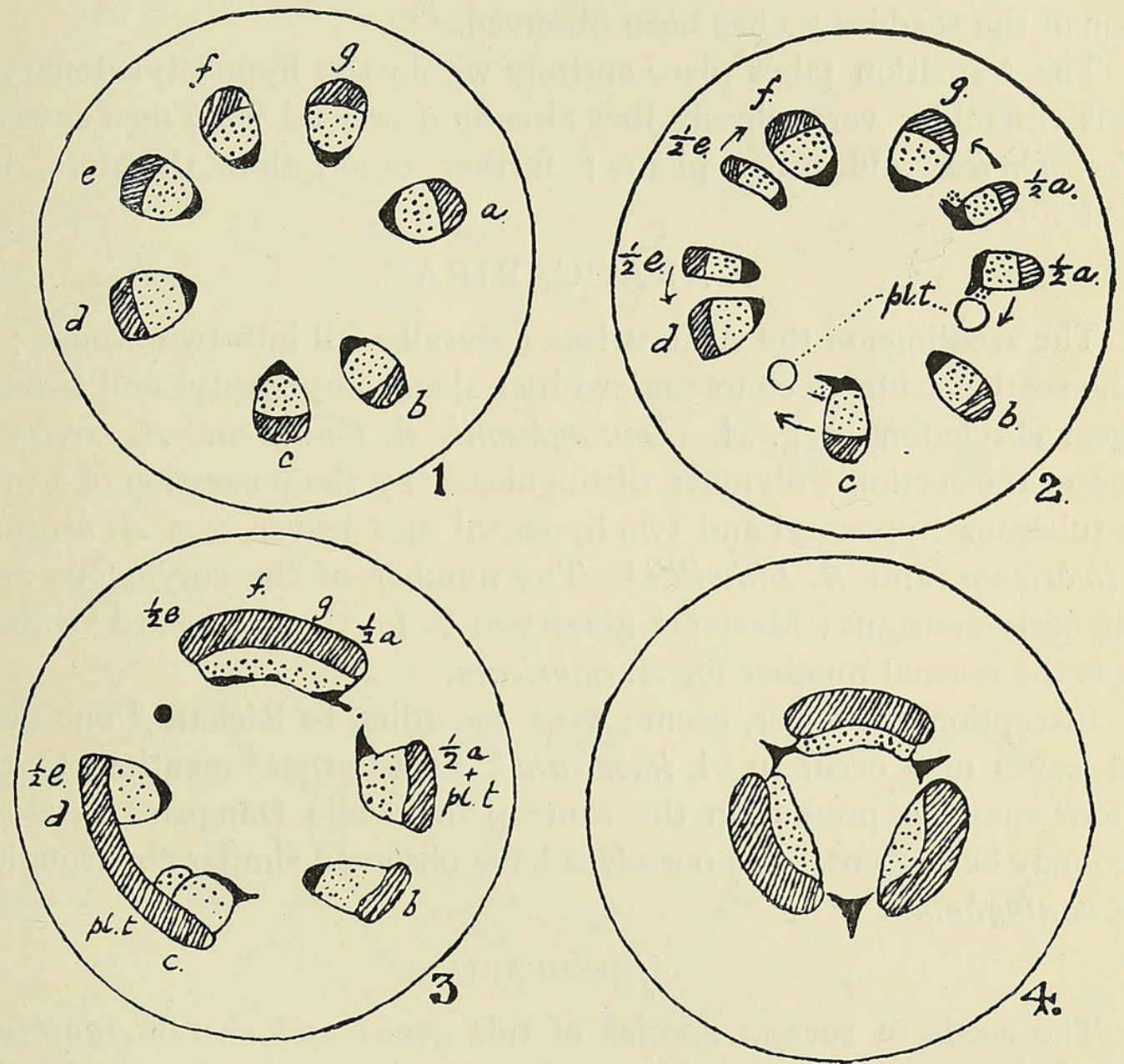

DiAgRam 8. Larix europaea.

passes over to one side. Here, again, the fusion of the two parts of $e$ with the strands $d$ and $f$ is very complete, and the combined protoxylems of the compound bundles, $d+\frac{1}{2} e$, and $f+\frac{1}{2} e$, rotate to form the remaining pole of the root (Diagram 8, Fig. 4).

In all the foregoing plants no difficulty has been encountered in determining whether any particular strand is the bundle of a whole-cotyledon, or of a half-cotyledon, or of a subsidiary seed-leaf; in the case of a whole-cotyledon the bifurcation and rotation of the two xylem masses is generally very strongly marked, but in this particular seedling the strands $a$ and $e$ 
fuse up with adjoining structures before any rotation begins so that it is possible to give values other than those assigned; for instance $d, e$, and $f$ might conceivably be the strands of a cotyledon which had split into three parts, so that the existing structures are really the third portions of a cotyledon.

\section{PSEUDOLARIX.}

Pseudolarix Kaempferi, Gord. The number of cotyledons is four or five, which resemble in their structure those of Larix leptolepsis and L.europaea. No cotyledonary tube is formed, and no tendency towards the basal fusion of the seed-leaves has been observed.

The transition takes place entirely within the hypocotyledonary axis, and it resembles very closely that already described for Tsuga canadensis, Abies sibirica, and other plants; further description, therefore, is uncalled for.

\section{ARAUCARIEAE.}

The seedlings of the Araucarieae naturally fall into two groups; those of the section Eutacta characterized by a slender hypocotyl and two to four epigeal cotyledons, e.g. A. Cunninghamii, A. Cookii and $A$. excelsa; and those of the section Colymbea distinguished by the possession of a more or less tuberous hypocotyl and two hypogeal seed-leaves, e. g. A. brasiliensis, A. imbricata, and $A$. Bidwillii. ${ }^{1}$ The number of the cotyledons appears to be fairly constant; Masters ${ }^{2}$ gives two to four, and Richard ${ }^{3}$ states that two is the normal number for $A$. imbricata.

Exceptions, however, occur ; thus, according to Richard, ${ }^{3}$ one or three seed-leaves may occur in A. imbricata. Strasburger ${ }^{4}$ mentions that three or four may be present in the same plant, while Dangeard ${ }^{5}$ states that three may be present. We ourselves have observed similar abnormalities in A. Cunninghamii.

\section{ARAUCARIA.}

The seeds of several species of this genus, and also of Agathis, were planted, but two species only germinated, Araucaria Cunninghamii and A. brasiliensis.

A. Cunninghamii, Forbes. The external appearance of a normal seedling of this plant is illustrated in Fig. $4 \alpha$, Plate XV. The cotyledons are epigeal and, apparently, four in number, arranged in two well-marked

${ }^{1}$ See Seward and Ford: The Araucarieae, recent and extinct (Phil. Trans. Roy. Soc. Lond., B. 247,1906$)$.

${ }_{2}$ Masters: Notes on the Genera of Taxaceae and Coniferae (Journ. Linn. Soc. Lond., Bot., $\mathrm{xxx}, \mathrm{I} 895)$.

${ }^{3}$ Richard: Commentatio botanica de Coniferis et Cycadeis (Stuttgart, I826).

Strasburger: Die Coniferen und die Gnetaceen (Jena, I8 $87^{2}$ ).

Dangeard, loc. cit, 
pairs. A more careful examination shows that the members of each pair fuse together immediately above the cotyledonary node, thus having the appearance of a two-pronged fork with a short handle, which suggests that each pair has been derived by the longitudinal fission of a single structure. Fig. $4 b$, Plate XV, represents an abnormal seedling with seemingly three cotyledons; really, one with two slender prongs and one single member.

Structure. The epidermis is covered with a thick cuticle, and so also is the outer surface of the guard-cells of the stomates, which are sunken well
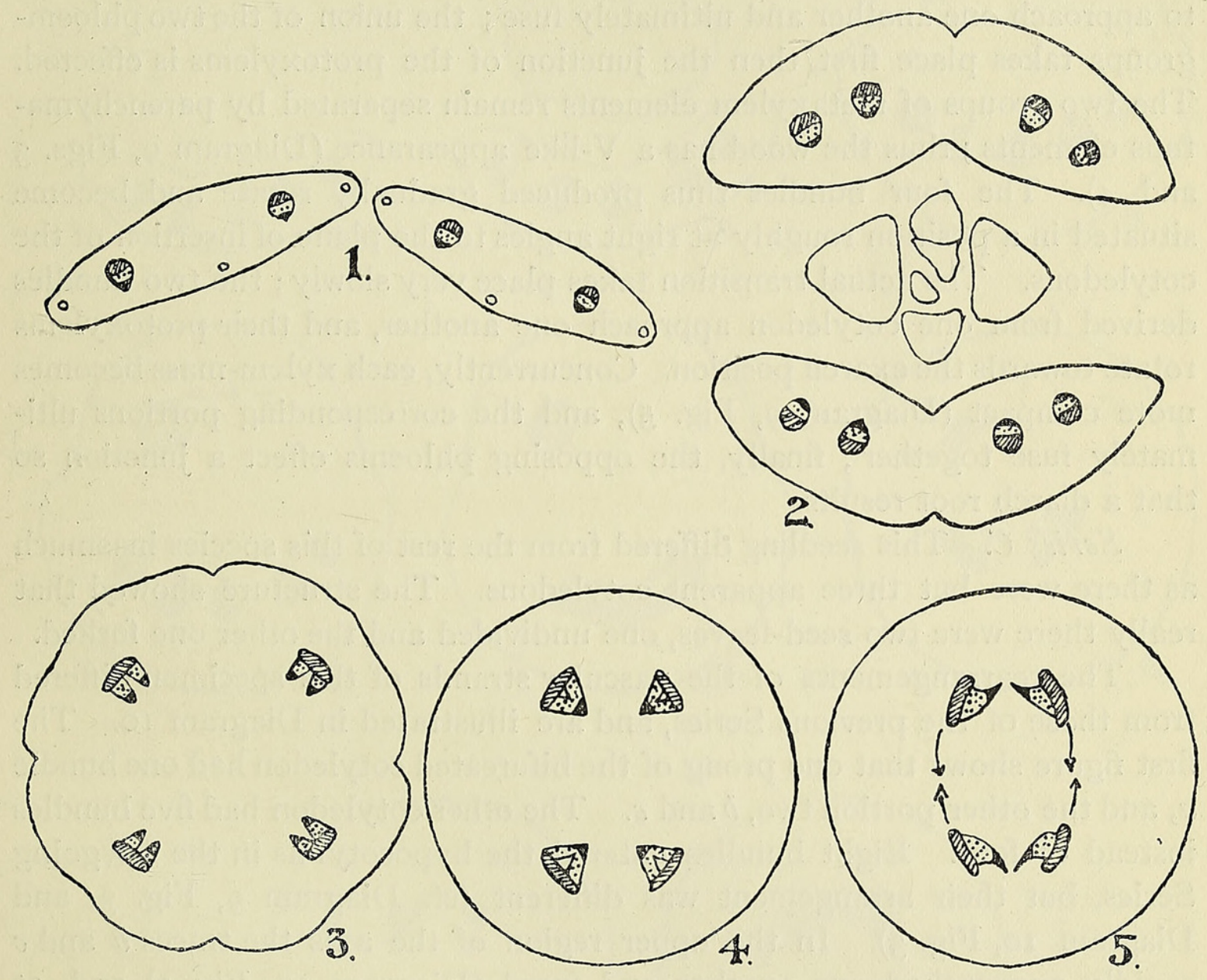

DiAgram 9. Araucaria Cunninghamii.

below the general level of the epidermis; secretory cells are abundant and each prong of a cotyledon has three resin ducts in the upper region, situated one at each end and the third just beneath the hypodermis in the middle line of the ventral side (Diagram 9, Fig. I). In the lower regions the resin ducts become more numerous, some being situated in the mesophyll. The vascular bundles are endarch and collateral throughout the whole length of the cotyledon and, at the extreme tip, consist only of tracheae. Transfusion elements are fairly common, more especially in the apical region. 


\section{Transition.}

Series $A$ and $B$. Each fork of the bifurcated cotyledons contains two vascular strands, well separated one from the other (Diagram 9, Fig. I); in the basal region of each cotyledon, below the fork, there are obviously four bundles arranged in two pairs (Diagram 9, Fig. 2). No union of bundles takes place in the cotyledons themselves, so that eight vascular strands arranged in four pairs enter the hypocotyl. The individuals of each pair of bundles, derived from the four prongs of two-forked cotyledons, continue to approach one another and ultimately fuse ; the union of the two phloemgroups takes place first, then the junction of the protoxylems is effected. The two groups of metaxylem elements remain separated by parenchymatous elements; thus the wood has a V-like appearance (Diagram 9, Figs. 3 and 4). The four bundles thus produced gradually rotate and become situated in a position roughly at right angles to the plane of insertion of the cotyledons. The actual transition takes place very slowly; the two bundles derived from one cotyledon approach one another, and their protoxylems rotate towards the exarch position. Concurrently, each xylem-mass becomes more compact (Diagram 9, Fig. 5), and the corresponding portions ultimately fuse together; finally, the opposing phloems effect a junction so that a diarch root results.

Series $C$. This seedling differed from the rest of this species inasmuch as there were but three apparent cotyledons. The structure showed that really there were two seed-leaves, one undivided and the other one forked.

The rearrangements of the vascular strands of this specimen differed from those of the previous Series, and are illustrated in Diagram Io. The first figure shows that one prong of the bifurcated cotyledon had one bundle $a$, and the other portion two, $b$ and $c$. The other cotyledon had five bundles instead of four. Eight bundles entered the hypocotyl as in the foregoing Series, but their arrangement was different (cf. Diagram 9, Fig. 3, and Diagram I0, Fig. 3). In the upper region of the axis the traces $b$ and $c$ rapidly approached one another and fused (Diagram IO, Fig. 3), and, at a lower level, this compound bundle fused on to the strand $a$ (Diagram Io, Fig. 4). Thus there were six bundles, five in one group derived from the undivided seed-leaf, and one derived from the forked cotyledon. The five strands fused together (Diagram Io, Fig. 5) and then separated out as two single structures (Diagram IO, Fig. 6), which behaved in the same way as in the previous Series and formed one pole of the diarch root. The single strand $a+b+c$ underwent a lateral displacement, and its protoxylem commenced its rotation towards the exarch position; then, in a corresponding position on the other side of the hypocotyl, a new group of phloem elements appeared which gradually became more abundant, and were followed by the appearance of xylem (Diagram I0, Figs. 7 and 8). A new bundle was 
thus organized which balanced the original single structure, and the two together formed the other pole of the diarch root.

The facts of the transition corroborate the view, based on the external morphology, that there are really only two cotyledons in this species ; and as the resemblance between the seedling of this species and those of
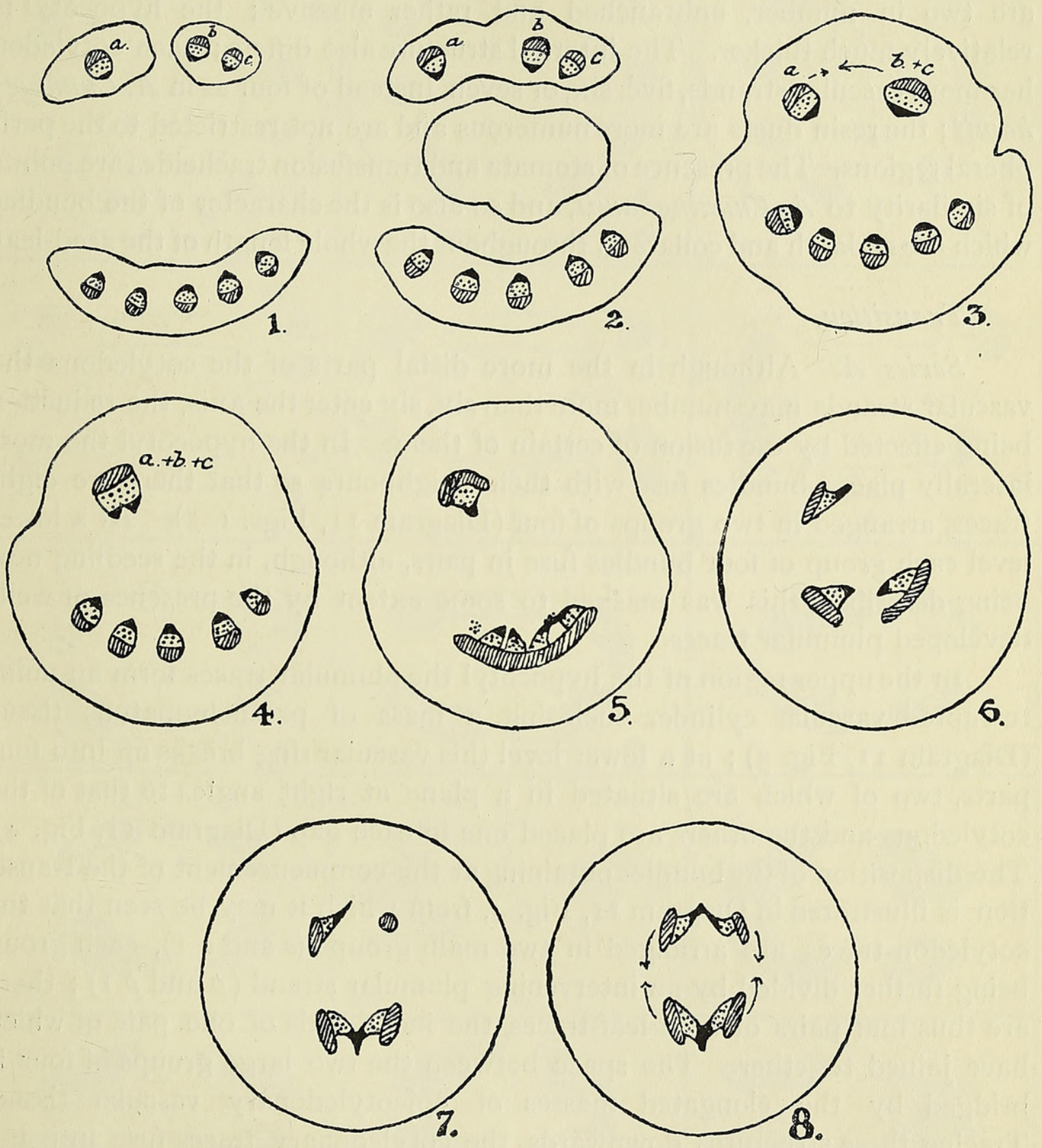

Diagram Io. Araucaria Cunninghamii.

A. excelsa and $A$. Cookii, as indicated by the published illustrations, ${ }^{1}$ is extremely close, the description of the species of the section Eutacta appears to require some emendation. Rather they should be described as having typically two cotyledons, each of which is forked. At the same time 
this feature may prove to be very obscure in some species, for the fission only requires to be extended a very little further to completely divide each seed-leaf into two.

Araucaria brasiliensis.

The seedling of this species differs from that of $A$. Cunninghamia in the following more or less important features:-it is hypogeal ; the cotyledons are two in number, unbranched and rather massive; the hypocotyl is relatively much thicker. The internal structure also differs ; each cotyledon has more vascular strands, five, six, or seven, instead of four as in $A$. Cunninghamii ; the resin ducts are more numerous and are not restricted to the peripheral regions. The presence of stomata and transfusion tracheides are points of similarity to $A$. Cunninghamii, and so also is the character of the bundles which are endarch and collateral throughout the whole length of the seed-leaf.

\section{Transition.}

Series A. Although in the more distal parts of the cotyledons the vascular strands may number more than six, six enter the axis, the reduction being effected by the fusion of certain of them. In the hypocotyl the most laterally placed bundles fuse with their neighbours so that there are eight traces, arranged in two groups of four (Diagram I I, Figs. I-5). At a lower level each group of four bundles fuse in pairs, although, in the seedling now being described, this was masked to some extent by the presence of welldeveloped plumular traces.

In the upper region of the hypocotyl the plumular traces form an uninterrupted vascular cylinder enclosing a mass of parenchymatous tissue (Diagram II, Fig. 3) ; at a lower level this vascular ring breaks up into four parts, two of which are situated in a plane at right angles to that of the cotyledons and the others are placed one in each gap (Diagram I I, Fig. 4). The disposition of the bundles obtaining at the commencement of the transition is illustrated in Diagram II, Fig. 4, from which it may be seen that the cotyledon-traces are arranged in two main groups ( $c$ and $c \mathrm{I}$ ), each group being further divided by an intervening plumular strand ( $p$ and $p \mathrm{I})$; there are thus four pairs of seed-leaf-traces, the individuals of one pair of which have joined together. The space between the two large groups of four is bridged by the elongated masses of epicotyledonary vascular tissue. Tracing these structures downwards, the cotyledonary traces fuse in pairs, move inwards, and join on to the large masses of plumular vascular tissue ( $e$ and $e$ I). A comparison of Figs. 5, 6, and 7 in Diagram II shows that the details of this movement are not precisely the same on each side of the axis. The cotyledon-traces $c$, on the left side, fuse with the intervening plumular strand $p$, and forming a broad band of vascular tissue which, however, soon separates into two parts, one half joining with $e$ and the other portion with $e \mathrm{I}$. The strands, on the right side, $c \mathrm{I}$, join up with $e$ and $e \mathrm{I}$ 
without any previous fusion and subsequent splitting. These changes lead to the formation of two bands of vascular tissue, each of which immediately divides into two parts. Avoiding subsidiary features for the time being, these

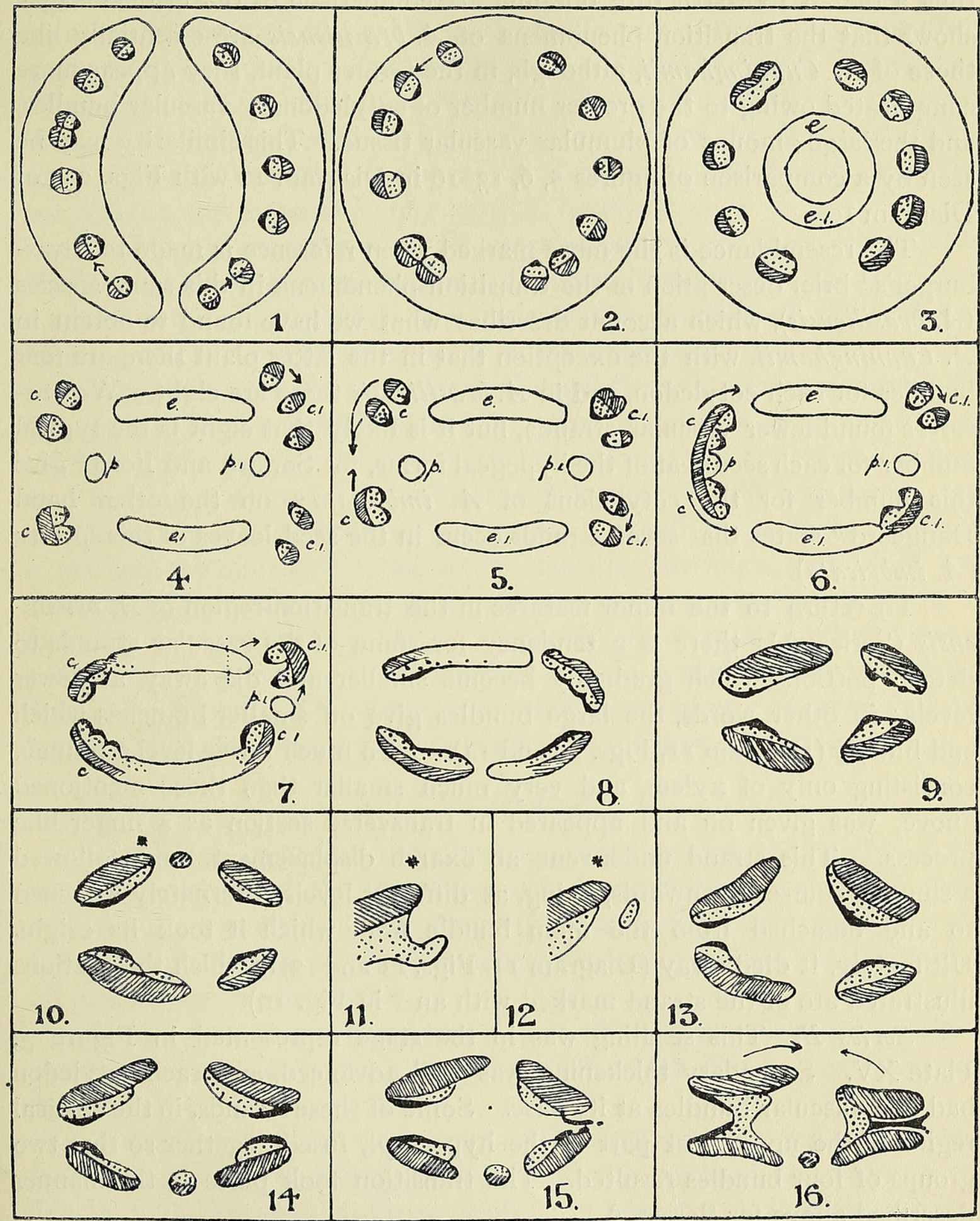

Diagram II. Araucaria brasiliensis.

four strands each have an endarch protoxylem, a point to which Masters ${ }^{1}$ has drawn attention, which gradually becomes concentrated towards the outer parts until its position is fully exarch (Diagram II, Figs. 8-10 and 
I $\left.3^{-I} 5\right)$. At the same time the opposing bundles move towards the cotyledonary plane until their metaxylems are contiguous (Diagram I I, Fig. I6); at a lower level the corresponding groups of phloem elements join together; thus a diarch root-structure obtains. A comparison of the critical stages shows that the transition phenomena of $A$. brasiliensis are essentially like those of $A$. Cunninghamii, although, in the former plant, they appear more complicated owing to the greater number of cotyledonary vascular bundles, and the large amount of plumular vascular tissue. This similarity may be seen by a comparison of figures $5,6, \mathrm{I}_{3}-\mathrm{I} 6$ in Diagram II with Figs. $2-5$ of Diagram IO.

The resemblance is the more marked when reference is made to Strasburger's ${ }^{1}$ brief description of the transition-phenomena in this same species (A. brasiliensis), which account describes what we have found to obtain in $A$. Cunninghamii, with the exception that in the latter plant there are four bundles for each cotyledon, and in $A$.brasiliensis there are eight. We ourselves found fewer vascular strands, but it is likely that eight is the typical number for each seed-leaf of the hypogeal forms, for Seward and Ford ${ }^{2}$ give this number for the cotyledons of $A$. imbricata; on the other hand Dangeard ${ }^{3}$ states that seven strands occur in the seed-leaves of this species (A. imbricata).

To return to the minor features in the transition-region of $A$. brasili. ensis (Series A); there is a tendency for some of the vascular strands to detach portions which gradually become smaller and die away at lower levels; in other words, the large bundles give off smaller branches which end blindly (Diagram II, Figs. IO and 14). At a much lower level a branch, consisting only of xylem, and very much smaller than those mentioned above, was given off and appeared in transverse section as a finger-like process. This strand underwent an exarch displacement, and followed a sinuous course downwards, being, at different levels, alternately attached to and detached from the main bundle from which it took its origin. Ultimately, it died away (Diagram II, Figs. II and I2, in which the portions illustrated are of the strand marked with an ${ }^{*}$ in Fig. IO).

Series $B$. This seedling was in the stage represented in Figure 5, Plate XV. Secondary thickening was well advanced, and each cotyledon had five vascular bundles at its base. Some of these strands, in the cortical region of the uppermost part of the hypocotyl, fused together so that two groups of four bundles resulted. The transition took place in the manner described above for Series A.

The seedling anatomy of $A$. imbricata has been described by Dangeard ${ }^{4}$ and Seward and Ford. ${ }^{5}$ Dangeard states that at the base of the cotyledons the bundles unite tangentially to form two large elongated strands, which in the hypocotyl divide into two. Thus there are four large bundles which
1 loc. cit.
${ }^{2}$ loc. cit.
${ }^{3}$ loc. cit.
${ }^{4}$ loc. cit.
${ }^{5}$ loc. cit. 
form the diarch root-structure in the manner already indicated. The account given by Seward and Ford for this same plant does not agree with that given by Dangeard in respect to the union of the cotyledonary bundles at the base of the seed-leaves. It appears, however, that there may be some variation as regards this particular feature, for we have described a tangential union of the seed-leaf-traces in A. Cunninghamii (Series C), and on one side of the seedling in $A$.brasiliensis (Series A). With this exception there is no material difference, and a comparison of the descriptions and corresponding illustrations warrants the conclusion that $A$. imbricata does not differ in any material feature from $A$. brasiliensis.

If the rearrangements of the vascular strands in these seedlings of Araucaria be traced in the opposite direction, from the root upwards, they may be summarized thus:-each pole of the diarch root gives off two bundles, which, during their passage to the cotyledons, first rotate to bring the protoxylems into the endarch position and then dichotomize, once in the case of $A$. Cunninghamii, and ideally twice in the case of $A$. brasiliensis, and some other hypogeal forms, so that the former has four bundles in each seed-leaf and the latter eight, subject to reduction in some instances.

If reference be made to Podocarpus, ${ }^{1}$ it will be seen that there is a marked resemblance in the actual transition between that plant and Araucaria ; in each case the upper regions of the hypocotyl are occupied by four cotyledonary bundles, two on each side, which rotate and give rise to a diarch root-structure, a fact which is clearly brought out in the relative figures. The only difference is that each seed-leaf in Podocarpus has two bundles, while in Araucaria there are typically either four or eight.

\section{ConCLusions.}

The chief immediate conclusion arrived at by the study of the seedling-structure of the Taxaceae and Araucariaceae is that the polycotyledonous condition, in the majority of cases, has been attained by the longitudinal division of the pre-existing single members which were in all probability two in number.

Before reviewing our evidence upon which this conclusion is based, some mention must be made of earlier work, which directly bears upon the subject.

The botanists of the earlier part of the nineteenth century were divided in their opinions regarding the nature of polycotyledony. Adanson and Jussieu both believed that the multiplicity of seed-leaves was more apparent than real, and that it had arisen by the division of two cotyledons, which opinion was not shared by Salisbury and Richard.

Duchartre $^{2}$, on the evidence summarized above (p. I 89), shared the belief of the two former investigators. 
Coming to more recent times, Sachs ${ }^{1}$ made the following statement: 'The Taxineae and most Cupressineae and Araucarieae have two opposite cotyledons, although in some Cupressineae there are from three to nine, and in some Araucarieae whorls of four cotyledons; while among the Abietineae there are rarely so few as two, more often four, or even as many as fifteen. To refer this larger number of cotyledons to the division of two opposite ones, as Duchartre proposes, is entirely opposed to the other processes of leaf-formation in these plants, especially to the common occurrence of whorls consisting of several leaves on the growing axis of seedlings.' This disbelief was seemingly shared by Masters, ${ }^{2}$ who, after mentioning the opinion of Adanson and his followers, remarked: 'If, however, the vascular bundles be traced from the caulicle [hypocotyl], it will be seen that the vascular cylinder breaks up not first into two divisions, which subsequently branch, but into a variable number not always in direct relation to the number of cotyledons.'

Dangeard ${ }^{3}$ recognizes that polycotyledony may have arisen either by the intercalation of members of the first foliage whorl between the existing cotyledons, or by the splitting of the original seed-leaves. He examines both hypotheses, and, discarding the former, he says, 'Nous pensons que l'augmentation du nombre des cotylédons chez les Gymnospermes provient de la division de deux larges cotylédons ; cette transformation s'est effectuée, dans la série des temps géologiques, sur un type voisin des Araucaria: mais ces deux cotylédons ont perdu actuellement toute individualité, elle s'est fragmentée pour ainsi dire en nouvelles individualités bien caractérisées.'

Clearly botanical opinion is divided, and it must be owned that the proof advanced in support of the contention of Adanson and Jussieu leaves much to be desired.

We may now pass on to the examination of our own evidence.

The Taxeae, Podocarpeae, and many of the Cupressineae, are characterized by the possession of two cotyledons ; each of them, with the exception of those of the Podocarpeae, has a single vascular bundle which undergoes a bifurcation and a more or less well-marked rotation of the xylem elements to produce one pole of a diarch primary root. The Abietineae, with the exception of the Araucarieae, are tri- to polycotyledonous; each seed-leaf again has a single vascular strand, with certain exceptions which will be considered below, but the primary root may be diarch, triarch, tetrarch, and so on, the number of poles bearing no obvious relation to the number of cotyledons, ${ }^{4}$ a feature which has struck more than one observer. ${ }^{5}$ The

${ }^{1}$ Sachs: Textbook of Botany, 2nd ed. (Oxford, I882, p. 507 ).

2 I 89 I, loc. cit.

${ }^{3}$ Dangeard: Plantules des Conifères (Le Botaniste, sér. $3,189^{2}$, p. 196).

${ }^{4}$ See the table at the end of this paper.

${ }^{5}$ Van Tieghem, Chauveaud, \&c., op. cit. 
behaviour of the bundles of the seed-leaves of these polycotyledonous forms must therefore vary in the same plant. The statement of our observations on the behaviour of the cotyledonary traces, contained in this present communication and in the first part of this research (Annals, '08), very strongly brings out the fact that the seed-leaves, as judged by the behaviour of their bundles in the transition-region, naturally fall into three categories, viz. (a) whole cotyledons, characterized by the bundle of each forming one pole of the root; $(b)$ half-cotyledons, which are recognized by the bundles of two of them being required to form one pole of the root-structure; and (c) subsidiary cotyledons, the strands of which have no influence on the number of bundles in the root-structure.

Attention has already been drawn (p. 209) to the conclusions arrived at by Chauveaud in this connexion.

Any or all of these classes of seed-leaves may be represented in one seedling.

The external morphology is not infrequently useful in this present connexion; attention already has been drawn to the occurrence of seedleaves partially split in the longitudinal direction, e.g. Cupressus torulosa, Abies sibirica, Pinus montana, var. gallica, and Araucaria Cunninghamii; and also to some cotyledons of a larger growth than their fellows, e. g. Pinus contorta, var. Murrayana. Again, seedlings have sometimes been seen in which the seed-leaves were obviously grouped together, a fact already recorded by Duchartre, ${ }^{1}$ who stated that this grouping is more evident in the embryo than in the seedling. Finally, Mrs. Tansley ${ }^{2}$ has described the cotyledons of Torreya as showing a marked tendency to lobing, and other observers have recorded the same thing for the Cycads and for Ginkgo. ${ }^{3}$

There is thus an abundance of macroscopic evidence partly to justify the above conclusion; but, at the same time, if this hypothesis be correct, the examination of a large number of plants should provide some transitional cotyledons, in which the bundles should be more or less divided and accompanied by an actual division of the seed-leaf itself to a degree more or less corresponding. Such examples are not wanting.

Pinus contorta, var. Murrayana (Series K), had three entire seed-leaves, one very much larger than the rest, and having two vascular strands entirely separate throughout the whole length of the member. These two bundles rotated towards one another within the axis and together formed one pole of the root. This is a case of one whole-cotyledon on the way to the formation of two half-cotyledons (Diagram 5).

Pinus montana, var. gallica (Series B). Two of the three seed-leaves were split longitudinally at their apices, and each of them had two vascular 
strands entirely separate one from the other. The bundles of one of these partly-divided cotyledons behaved in exactly the same manner as obtained in the similar case of $P$. contorta, var. Murrayana (Series K), mentioned above. The bundles of the other bifurcated cotyledon behaved differently; one took no part in the transition and was therefore subsidiary, while the other underwent the equal division and rotation associated with the strands of a whole-cotyledon. Thus we have an example of the formation of two half-cotyledons from a whole-cotyledon, and also the formation of a subsidiary seed-leaf from a whole-cotyledon.

Another plant (Series C) of this same species provides a similar instance of the formation of a subsidiary cotyledon from a pre-existing single structure; in this case, however, there is a further advance, for the cotyledon in question was split more deeply. Araucaria Cunninghamii in which the two cotyledons are deeply bifid, may also be cited.

These examples, taken in conjunction with the other facts mentioned above, furnish a proof as complete as may be expected, but our hypothesis, on first thoughts, apparently does not lead us any great distance; for we can, so far, only derive a seedling with, say, ten half-cotyledons from a form which had five whole-seed-leaves, which is some way removed from the simpler condition of two cotyledons obtaining in Taxus, \&c.

The examination, however, of the foregoing plants has provided several instances which show that this difficulty is more apparent than real. Many seedlings exhibited cotyledons, the bundles of which behaved differently from what they should if they had been of an absolutely rigid nature. In other words, it does not follow that because a seed-leaf is a subsidiary cotyledon, or a half-cotyledon, that therefore it will always remain as such; a subsidiary seed-leaf may, in the course of events, be promoted, as it were, to the rank of a half-cotyledon; while a half-seed-leaf may be raised to the dignity of a whole-cotyledon.

The following examples have a bearing on this particular point :-

Cedrus atlantica (Series A). One bundle commenced to rotate in the manner usually associated with that of a half-cotyledon, but the movement came to nothing, and the strand in question finally behaved as that of a subsidiary seed-leaf.

Pinus Coulteri (Series A and B). A bundle from a seed-leaf bifurcated and commenced to rotate exactly like the strand of a whole-cotyledon, but finally it acted like a trace of a half-cotyledon.

Pinus australis, P. insignis, and Abies balsamea showed the same thing in a more marked degree.

Pinus contorta, $P$. contorta, var. Murrayana, P. insignis, and $P$. sylvestris, provided many examples of the bundles of cotyledons dividing and rotating within the seed-leaves in the manner they should if they belonged to whole-cotyledons. The bifurcation was sometimes very unequal (see 
Diagram 7, and Fig. 3, Pl. XV), and the smaller portion often died away so that the strands finally performed as those of half-cotyledons; in other cases the smaller portion of the divided bundles persisted, so that notwithstanding the unequal division the strand behaved right through as that of a whole cotyledon.

Thus we have instances of cotyledonary bundles with intermediate characteristics, and these we consider examples illustrating the promotion of seed-leaves from a lower rank to a higher. There is thus no difficulty in the conception of the origin of a polycotyledonous from a dicotyledonous seedling by the process of splitting and promotion.

At the same time, we do not desire to maintain that this is the invariable rule : tricotyledonous seedlings may be due to nothing more than the formation of three seed-leaf primordia instead of the normal number, such as obtains in many seedlings of Dicotyledons, e. g. Anemone sp. and Salicornia herbacea; further, we have drawn attention to the fact that some subsidiary seed-leaves may be due to the displacement of leaves from the first foliage whorl to the cotyledonary node, as in Cedrus Deodara and Pinus Pinea. ${ }^{1}$

It may be mentioned here that Tansley and Thomas ${ }^{2}$ have arrived at similar conclusions.

As regards the reasons for this multiplicity of seed-leaves, Masters ${ }^{3}$ has stated his opinion that 'It is possible that an increased number of cotyledons might, under certain circumstances, be advantageous by securing a larger surface and a better chance in the competition with the neighbouring herbage'. Avebury ${ }^{4}$ has suggested that the reason for the deeply bifid cotyledons in several plants, e.g. Schizopetalon Walkeri, and Opuntia basilaris, is to enable them to be withdrawn more easily from the seed, and he asks the question 'Is it possible that the multiplicity of the cotyledons in Conifers can be due to the same cause?'

In all cases we have found the mesophyll of the cotyledons to be homogeneous in structure, and the parenchyma never shows the internal shelves or flanges which is so characteristic a feature in the chlorenchyma of the foliage leaves of so many Gymnosperms; thus the available surface in the seed-leaves for the exposure of the chloroplasts is more limited than is often the case in the foliage leaves. We therefore think that it is not altogether improbable that the longitudinal fission of the cotyledons is a means to obtain a greater surface ; for these structures persist relatively for a long time, and are thus important contributors to the synthetic foodmaterial of the young plant.

1 Cf. Dangeard, loc. cit.

${ }^{3}$ Masters, I 89 I, loc. cit.
2 Brit. Assoc. York. Sect. K, I906,

4 On Seedlings, p. $5^{2}$. 


\section{SUMMARY.}

\section{Cotyledons.}

I. The number of cotyledons varies: the hypogeal species of Araucaria have two, the epigeal also have two, which may be divided so deeply as to form apparently four; Tsuga seldom has more than three; the species of the other genera examined may have from three upwards (see table below).

2. Some of the seedlings possess a more or less well-marked cotyledonary tube, e. g. Pinus Pinea, P. canariensis, P. contorta, var. Murrayana, $P$. montana, var. gallica, $P$. sylvestris, Abies pectinata, A. amabilis, Picea ajanensis, Cedrus atlantica, and $C$. Deodara. In the following plants certain of the cotyledons fuse laterally at their bases so that an incomplete tube is produced, Pinus Pinea, $P$. Gerardiana, $P$. halepensis, $P$. australis, $P$. insignis, $P$. contorta, var. Murrayana, $P$. montana, var. gallica, $P$. sylvestris, Larix, Abies sibirica, and Picea morinda.

3. Some seed-leaves exhibit a longitudinal split from the apex towards the base, e.g. Cupressus torulosa, Abies sibirica, and Pinus montana, var. gallica. This division is constant and extends almost to the base in Araucaria Cunninghamii.

4. Resin ducts are generally present. In the following, each cotyledon has two canals situated one at each dorsal corner, A. sibirica, A. Veitchii, A. balsamea, A. amabilis, A. magnifica, var. Shastensis, Cedrus Deodara, Pinus Pinea, P. Gerardiana, P. canariensis, Larix europaea, L. leptolepis, and Pseudolarix Kaempferi. In the following plants, each seed-leaf has one resin duct, situated in the mesophyll immediately dorsal to, or by the side of (in the case of half-cotyledons), the vascular bundle. Pinus australis, $P$. insignis, $P$. contorta, $P$. contorta, var. Murrayana, $P$. montana, var. gallica, and $P$. sylvestris.

The Araucarias have several resin ducts in their cotyledons, while in the following plants no such canals have been observed: Tsuga, Abies pectinata, Picea, Pinus halepensis, $P$. Coulteri, and Larix occidentalis.

Resin-ducts are absent from subsidiary cotyledons and many halfcotyledons.

5. The mesophyll is, without exception, homogeneous.

6. The seed-leaves of Araucaria each contain several bundles (4-8), those of Tsuga, Abies, Picea, Cedrus, Pinus, and Larix each have one vascular bundle.

Exceptions, however, occur; one cotyledon of a seedling of $A$. Cunninghamii had three strands; two vascular bundles occurred in the cotyledons of a few seedlings of $P$ inus contorta, var. Murrayana, $P$. montana, var. gallica, and Larix europaea. 
7. Traces of a mesarch structure have been seen in the cotyledonary bundles of occasional plants of Tsuga canadensis, Pimus Pinea, and P. Gerardiana.

8. Transfusion tracheides are generally present, although the amount varies: they have not been observed in Abies pectinata and Cedrus.

9. Fibrous elements on the dorsal side of the phloem are generally present.

\section{TRANSITION-PHENOMENA.}

I0. In the following plants the vascular arrangement takes place within the hypocotyl, so that the bundles within the cotyledons are endarch and collateral :- Tsuga canadensis, $T$. diversifolia, Abies sibirica, A. Veitchii, A. balsamea, A. firma, A. Sachaliensis, A. pectinata, A. amabilis, A. magnifica, var. Shastensis, Picea ajanensis, P. nigra, P. morinda, Cedrus atlantica C. Deodara, Larix occidentalis, L. leptolepis, L. europaea, Psendolarix Kaempferi, Pinus Pinea, P. Thunbergii, P. Gevardiana, P. halepensis, Araucaria Cunninghamii, and A. brasiliensis.

In the following plants the bundles of some or all of the seed-leaves may bifurcate and rotate, more or less markedly, in the cotyledon itself :Pinus Coulteri, $P$. canariensis, $P$. australis, $P$. insignis, $P$. contorta, $P$. contorta, var. Murrayana, P. montana, var. gallica, and $P$. sylvestris.

II. The cotyledonary bundles behave differently in the vascular changes in the transition-region; and according to their behaviour the seed-leaves may represent whole-cotyledons, half-cotyledons, or subsidiary cotyledons (see above, Conclusions).

I2. When all the seed-leaves are whole-cotyledons, the transition follows Van Tieghem's Type 3 .

I3. Much variation in the transition occurs when the seed-leaves are mixed, i. e. when various combinations between the three kinds of cotyledons occur in the same species.

I4. The polycotyledonous condition has been derived from the dicotyledonous condition, in the vast majority of cases by the splitting of the seed-leaves and by the promotion of cotyledons from a lower to a higher rank. In a few cases, the number of seed-leaves has been increased by the displacement of foliage leaves from the first plumular whorl to the cotyledonary node.

15. The relations between the number and nature of the cotyledons and the root-structure is shown in the following table. 


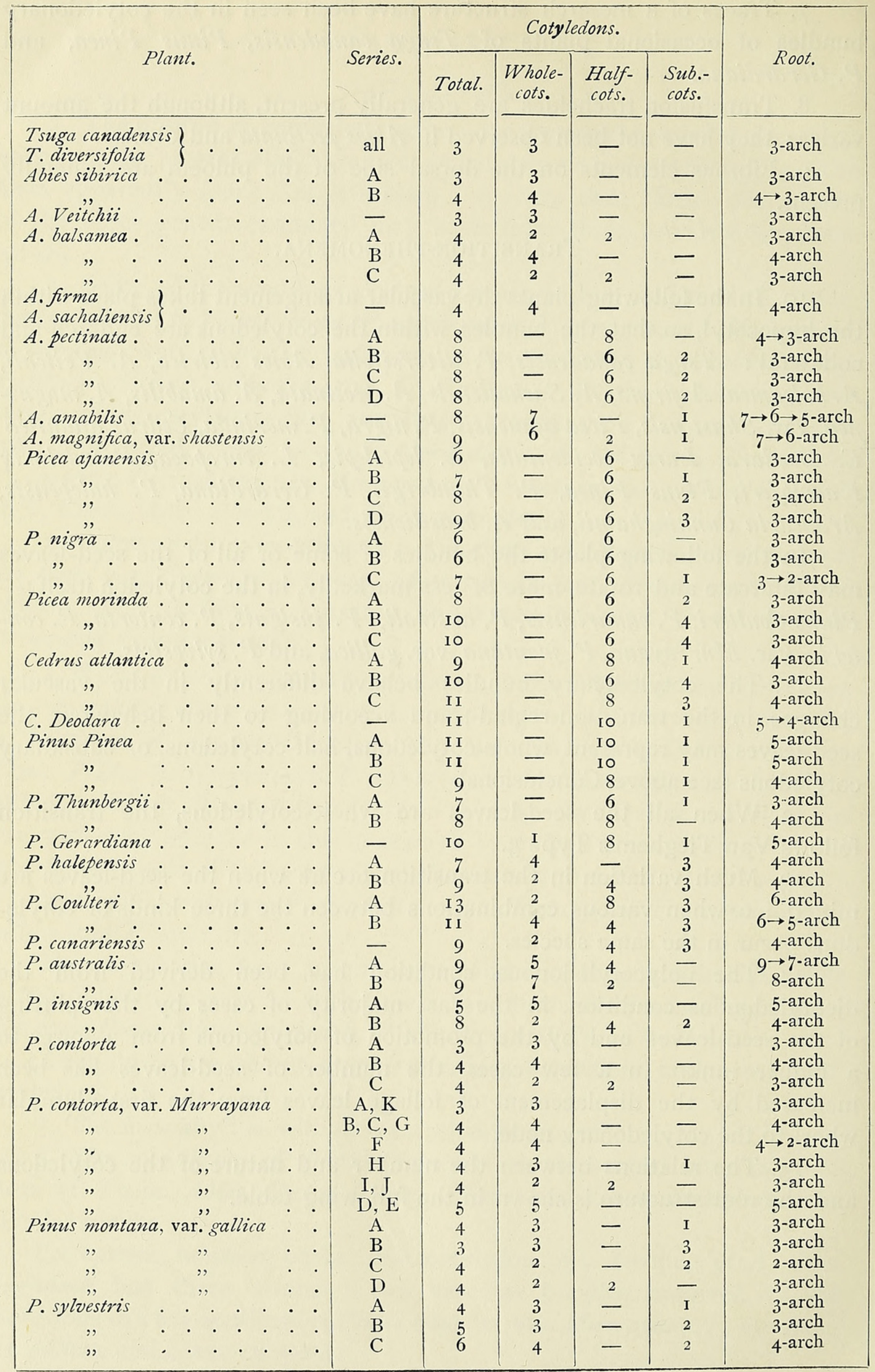




\begin{tabular}{|c|c|c|c|c|c|c|c|}
\hline \multirow{2}{*}{\multicolumn{2}{|c|}{ Plant. }} & \multirow[b]{2}{*}{ Series. } & \multicolumn{4}{|c|}{ Cotyledons. } & \multirow[b]{2}{*}{ Root. } \\
\hline & & & Total. & $\begin{array}{c}\text { Whole- } \\
\text { cots. }\end{array}$ & $\begin{array}{l}\text { Half- } \\
\text { cots. }\end{array}$ & $\begin{array}{l}\text { Sub.- } \\
\text { cots. }\end{array}$ & \\
\hline 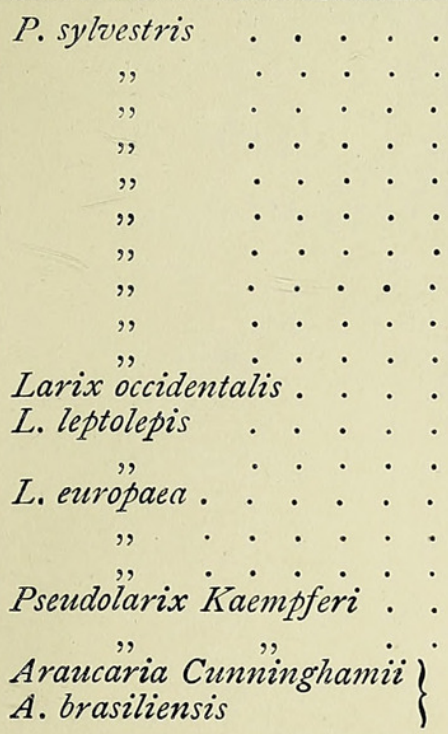 & 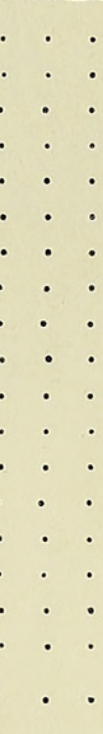 & $\begin{array}{l}\mathrm{D} \\
\mathrm{E} \\
\mathrm{F} \\
\mathrm{G} \\
\mathrm{H} \\
\mathrm{I} \\
\mathrm{J} \\
\mathrm{K} \\
\mathrm{L} \\
\mathrm{M} \\
\mathrm{A} \\
\mathrm{B} \\
\mathrm{A} \\
\mathrm{B} \\
\mathrm{C} \\
\mathrm{A} \\
\mathrm{B} \\
\text { all }\end{array}$ & $\begin{array}{l}6 \\
6 \\
6 \\
6 \\
6 \\
7 \\
7 \\
7 \\
7 \\
7 \\
6 \\
5 \\
6 \\
6 \\
6 \\
7 \\
5 \\
4 \\
2\end{array}$ & $\begin{array}{l}3 \\
2 \\
2 \\
2 \\
2 \\
\text { I } \\
4 \\
2 \\
\text { I } \\
\text { I } \\
3 \\
\text { I } \\
\text { I } \\
2 \\
\\
2 \\
2 \\
4 \\
4 \\
2\end{array}$ & $\begin{array}{l}\frac{-}{4} \\
2 \\
\frac{4}{4} \\
4 \\
6 \\
2 \\
4 \\
4 \\
4 \\
4 \\
\frac{2}{-} \\
-\end{array}$ & $\begin{array}{l}\frac{3}{4} \\
2 \\
\text { I } \\
3 \\
\text { I } \\
2 \\
2 \\
\text { I } \\
4 \\
2 \\
2 \\
3 \\
\text { I } \\
- \\
-\end{array}$ & $\begin{array}{l}\text { 3-arch } \\
\text { 4-arch } \\
\text { 2-arch } \\
\text { 3-arch } \\
\text { 3-arch } \\
\text { 4-arch } \\
\text { 4-arch } \\
\text { 3-arch } \\
\text { 4-arch } \\
\text { 4-arch } \\
\text { 3-arch } \\
\text { 3-arch } \\
\text { 2-arch } \\
\text { 2-arch } \\
\text { 2-arch } \\
\text { 3-arch } \\
\text { 4-arch } \\
\text { 4-arch } \\
\text { 2-arch }\end{array}$ \\
\hline
\end{tabular}

\section{EXPLANATION OF PLATE XV.}

Illustrating Mr. T. G. Hill and Miss de Fraine's Paper on the Seedling Structure of Gymnosperms. II.

Abbreviations :- $m x$. metaxylem; $p h$. phloem ; $p x$. protoxylem; $r . d$. resin-duct ; T.S. transverse section.

Fig. I. Pinus contorta, var. Murrayana (Series I). T. S. through upper region of hypocotyl. $\times 240$.

Fig. 2. The same, about $10 \mu$ below. $\times 240$.

Fig. 3. Pinus montana, var. gallica. T. S. of a cotyledonary bundle, showing unequal bifurcation of the vascular tissues. $\times 24^{\circ}$.

Fig. 4 a. Araucaria Cunninghamii. A normal seedling. Nat. size.

Fig. 4 b. Araucaria Cunninghamii. Cotyledons and upper part of hypocotyl of an abnormal seedling. Nat. size.

Fig. 5. Arancaria brasiliensis. Photograph of seedling. $\quad x$ about $\frac{3}{5}$. 
Annals of Botany.
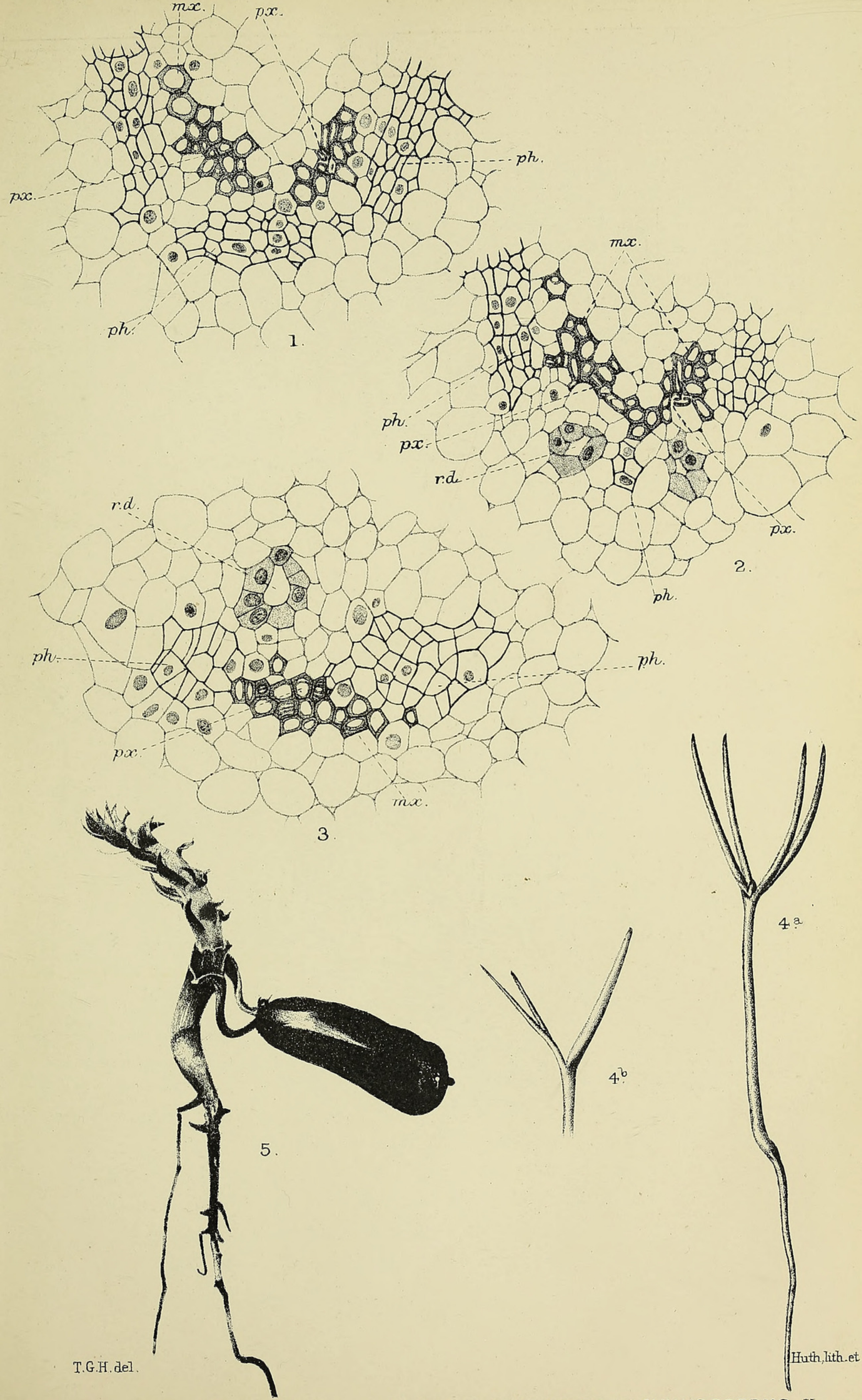

HILL AND DE FRAINE — SEEDLING STRUCTURE OF GYMNOSPERMS. II. 


\section{$2 \mathrm{BHL}$ Biodiversity Heritage Library}

Hill, T. G. and De Fraine, E. 1909. "On the seedling structure of gymnosperms. II." Annals of botany 23, 189-227. https://doi.org/10.1093/oxfordjournals.aob.a089211.

View This Item Online: https://www.biodiversitylibrary.org/item/236540

DOI: https://doi.org/10.1093/oxfordjournals.aob.a089211

Permalink: https://www.biodiversitylibrary.org/partpdf/318947

\section{Holding Institution}

Smithsonian Libraries

\section{Sponsored by}

Biodiversity Heritage Library

\section{Copyright \& Reuse}

Copyright Status: Not in copyright. The BHL knows of no copyright restrictions on this item.

This document was created from content at the Biodiversity Heritage Library, the world's largest open access digital library for biodiversity literature and archives. Visit BHL at https://www.biodiversitylibrary.org. 